\title{
When Privacy is Not Enough: Sexual assault COMPLAINANTS, SEXUAL HISTORY EVIDENCE AND The DisClosure of PERSONAL RECORdS
}

\section{LISE GOTELL}

How cant the righs of sexual assanh victims be balanced against the rights of the accused in a sexual assault case? Sexual assault remains one of the most under-reported crimes in Canada. largely due to the invasion that results once a sexual assault is reported. Distrust of the criminal justice system continues to deter reporting. Recem amendments to the Canadian Criminal Code aim to protect sexual assault complainants by regulating the introduction of sexual histon evidence and third-party records, such as counselling and therapy. However, courss in Canada have increasingly used a standard based on privacy law wo interpret thesc provisions. Does privacy law sorve as a useful framework by which to evaluate this legislation? This article explores the gendered issues of privacy law, challenges the privacy approach to the sexual assuult provisions of the Criminal Code, and explores a more balanced alternative.
De quelle momiere pewt-on équilibrer les droits des vicfimes dagression sexwelle el cent des accuses d'agression sexmelle?' Le's agressions sexuelles demeurem liun des crimes les moins signales at Canada, surtout en roison de l'alleinte à la vie privé qui en resulte une fois l'agression signalece. La méfiance à l'egard du surstème de justice pénale contimue d'en dissuader le signalement. De récents amendements au Code criminel du Canada visem à protéger les plaignamis en régissant la présentation d"antécedents sexwels comme ditements de prenwe er les dossiers de tiers, comme la comsultation en la thírapie. Cependom, les tribunam camadiens utilisent de plus en phus une nome baseje sur la loi sur le respece de la vie privée pour imerpriter ces dispositions. Cutse loi fournit-elle un cadre pratique pout évaluer cetse législation? L'article exomine les questions de genre de ce droit, questionme lapproche de vie privee relative aur dispositions dis Code criminel sur lagression sernelle et explore une solution de rechange plus iquilibrice.

\section{TABLE OF CONTENTS}

I. INTRODUCTION ............................... 744

II. The Gendered Paradoxes of Privacy ............... 746

1II. LEGISLATIVE RESTRICTIONS ON SEXUAL HISTORY EVIDENCE.

aNd CONFIDENTIAL RECORdS: CONTEXTUALIZING PRIVACY ....... 753

IV. THE PERMEABILITY OF RESTRICTIONS ON SEXUAL HISTORY

EVIDENCE AND CONFIDENTIAL RECORDS:

WhEN PRIVACY IS NOT ENOUGH $\ldots \ldots \ldots \ldots \ldots \ldots \ldots \ldots \ldots \ldots \ldots \ldots$

A. Perceptions of 1990s law Reforms and tie Cask

LAW THAT FORMS THE BASIS FOR THIS ANALYSIS .......... 755

B. The Mills and DaRRaCh DeCISIONS: Emphasizing PrIVACY AND PRIVILEgING LEgAL Rights $\ldots \ldots \ldots \ldots \ldots \ldots \ldots . \ldots 759$

C. Preventing "Fishing EXPEDITIONS": Lower COURT

DECISIONS ON RECORDS APPLICATIONS AND THE NFCESSITY

OF A CASE-SPECIFIC EVIDENTIARY FOUNDATION ......... 761

D. Carving Out Exceptions: General/SPecific, Sexual/

NON-SEXUAL AND SEXUAL HISTORY EVIDLNCE . . . . . . . 762

PhD., Associate Professor. Women's Studies, University of Alberta. I want to acknowledge the support of a SSHRC standard research grant. I am also grateful to the editors of the Alberra Law Review for the invitation to submit to this special issuc and to the anonymous reviewers for their evaluation of my submission. 
E. Carving Out Exceptions: Personal Records and the

"REasonable:" Expectation of Privacy .............. 764

F. Judicial Transformation OF the Balancing EXerCises

CONTEMPLATLD BY SECTIONS 276 AND 278: REDUCING OF

COMPLAINANTS' INTERESTS To Privacy ............... 766

G. The Fragllity of Privacy: "IDEAl Victim"

vs. ACtUAL COMPLAINANTS . . . . . . . . . . . . . . . 769

V. CONCLUSION: CONSEQUENCES AND THE NECESSITY OP:

Contextualizing Privacy . . . . . . . . . . . . . . . . . . 773

APPENdIX A: Post-MiLIS CASES ANALYZEd ............... 776

APPENDIX B: POST-DARRACH DECISIONS ANALYZED ........... 778

\section{INTRODUCTION}

It is not enough to decide that no means no; we must also decide when we are willing to accept that a woman said no. What do we need to know abuut her, and what will we protect as privale?'

This article addresses the complexities of privacy for those who are sexually assaulted and choose to report these assaults. As Susan Estrich asks, what is it that we need to know in order to believe a complaint of sexual assault? The answer to this question is most certainly a great deal indeed. Feminists have called attention to how a woman's interaction with the justice system mimics the violation of a sexual assault. ${ }^{2}$ From the time a phone call is made to the police, what begins is an almost Kafkaesque scenario in which a complainant's body and her words are transformed into evidence, with little sense of boundaries or privacy. The experience of medical evidence gathering, making a police statement, and sometimes engaging with Crown prosecutors and enduring a trial, leaves a sexual assault complainant with little autonomy, self-determination or control. The spectre of false complaints, fuelled by the long-standing belief that rape is an allegation "easily to be made" and "harder to be defended by the party accused, tho never so innocent," or child ${ }^{4}$ subject to a series of invasive defence practices designed to test and undermine credibility. While the concept of privacy holds a deep significance in criminal law, its jurisprudential elaboration under the Canadian Charter' has emphasized the entitlements of those suspected and accused of criminal wrongdoing. ${ }^{6}$ The sexual assault complainant occupies a position between the powerful state and a presumed innocent accused. Her

- Susan Estrich, "Palm Beach Slories" (1992) Il Law \& Phil. 5 at 32.

Wendy Larcombe, "The 'Ideal' Victim V Successful Rape Complainants: Not What You Might Expect" (2002) $10 \mathrm{Fem}$. Legal Stud. 131.

Sir Matthew Hale, The Jistony of the Pleas of the Crown, vol. I (London: Professional Books, 1971) at 635 .

$+\quad$ Sexual assault is a gendered crime. Eighty percent of victims of repencd sexual assaults were women. Male adolescents and children comprise the vast majority of male vietims of reported sexual assaults. Only 8 percent of adult sexual assault victims are men. Ninety-seven percent of those aceused of sexual assault are male (Rebecea Kong ef at., "Sexual Oftences in Canada" Jtristar 23:6 (July 2003) 1 at 1, 7). Canadion Charter of Rights and Freedoms, Part I of the Conssitumion Act, 1982, being Schedule $B$ to the Comada Act 1982 (U.K.), 1982, c. II [Charter].

- In reviewing privacy in the context ol'criminal law, Stanley Cohen fails to interrogatc (or even mention) the privacy rights of complainants (Stanlcy A. Cohen, "The Paradoxical Nature of Privacy in the Context of Criminal Law and the Canadian Charter of Rights and Freedons" 7 Can. Crim. L. Rev. 125). 
interests are very often aligned with the state's interest, such that her needs and rights are viewed as expendable, necessarily yielding in order to ensure a defendant's right to a fair trial.

In this article, I examine the fate and utility of legislative efforts designed to limit what it is that a woman/child complainant must be forced to reveal at trial as the price of her access to the criminal justice system. Specifically, I interrogate the judicial interpretation of Criminal Code provisions regulating the admissibility of sexual history evidence (s. 276) and defence access to complainants' confidential records (s. 278). ${ }^{\mathrm{x}}$ At issue within the case law on sexual history evidence and access to complainants' records are the strategies used to disqualify claims of sexual assault. Cross-examination on sexual history is a historically long-standing defence strategy, deployed to discredit the complainant through reducing her to a sexualized body - the unchaste seductress whose "no" must mean "yes" and whose story is rendered unreliable by her emphatic sexuality." Through revealing past sexual activity, the complainant is re-scripted as a precipitating agent in a sexualized scenario, with the intended effect of disqualifying her testimony. ${ }^{10}$ By contrast, seeking access to complainants' records is a relatively recent tactic, first emerging in Canada in the late 1980s." Probing diverse private records for evidence of inconsistency, to create the appearance of faulty memories and motive to lie, has provided a kcy mechanism of attacking complainants since the 1990s. ${ }^{12}$

See Criminal Code, R.S.C. 1985, c. C-46, s. 276 [CC]. The section prohibits the admission of sexual history evidence solcly for the purpose of showing that the complainant was more likely to have consenled or is less worthy of belief. It also requires that the evidence must be relevant to an issue to be proved at trial, and that it must have significant probative value that is not "outweighed by the danger of prejudice to the proper administration of justice." It further mandates that in determining relevance and probative value, the judge nust consider such factors as the accused's right to make full answer and defence, society's inlerest in the reporting of crime, the importance of eliminating any discriminatory belief or bias from the fuct-finding process, the risk that the evidence will arouse the jury's sentiments of prejudice, sympathy or hostility, the possible prejudice to the complainant's privacy and dignity, and the right of all persons to personal security and protection and benelit of the law.

CC, ibid., s. 278 establishes a two-step test for the production and disclosure of complainants' records. At the lirst stage, prior to viewing the records, the judge must determine whether the records meet a "likely relevance" standard, weighing the following factors: the necessity for full answer and defence, the probative value of the record, the extent of the reasonable expectation of privacy, the inlluence of discriminatory myths, privacy rights. the integrity of the trial process and sociely's interest in the reporting of sexual offences and the obtaining of treatment by complainants (s. 278.5(2)). The legislation further specifies a number of assertions which are, on their own, insuflicient to mett the test of likely relevance, including: the existence of the record, that the record may contain prior inconsistent statements, that the record may relate to the reliability of the witness because she has received therapy. that the record may reveal other allegations of sexual abuse, that the record relates to sexual reputation (s. 278.3(4)). If records pass this first-stage test, the judge reviews the records, considering the same set of factors in determining whether the documents or edited portions are to be turned over to the accused (s. 278.7).

Larcombe, supra note 2; Terese Henning \& Simon Bronitt. "Rapt Vietims on Trial: Regulating the Use and Abusc of Sexual History Lvidence" in Patricia Eastcal, ed. Baloncing the Scates: Rape. Law Reform and Anstraliom Culhure (Sydncy: Federation Press, 1998) 76. Carol Smart. Law. Crime amd Sexualin: Essays in Feminism (London: Sage, 1995) at 83-84.

At a widely publicized 1988 meting of Canadian eriminal lawyers. participants were counselled to "whack the complainant hard" by secking access to every imaginable personal record and to use these records as fodder for bnutal cross-examination (Cristin Schmit.. " 'Whack' sex assault complainant at preliminary inquiry" The Lonyers Weekly 8:5 (27 May 1988) 22).

12 Karen Busby, "Discriminatory Uses of Personal Records in Sexual Violence Cases"(1997) 9 C. J. W.L. 148 [Busby, "Discriminatory"]. 
It is not my intention to argue, however, that we must see these defence practices of sexual history interrogation and the pursuit of personal records simply as infringements on privacy rights. Instead, this article points towards the highly paradoxical nature of claiming privacy on behalf of sexual assault complainants. The first section of the article reviews the complexities and gendered dimensions of privacy, analyzing how the public/private divide has been deployed to shield sexual violence from public view, raising feminist critiques of traditional conceptions of privacy, and revealing how, in the contemporary period of neoliberalism, recognition of sexual assault as a social and political problem has been eroded through the mechanism of re-privatization. Next the article moves on to a discussion of feminist-inspired law reforms that produced legislative restrictions on sexual history evidence and access to private records. As I will demonstrate, these reforms located the harms of sexual history evidence and the production of confidential records in a complex set of concerns that extended well beyond traditional notions of privacy as a boundary around the individual. The third section of the article engages in an analysis of case law, beginning with Supreme Court decisions in R. v. Mills ${ }^{13}$ and R. v. Darrach, ${ }^{14}$ upholding ss. 278 and 276 respectively against constitutional legal rights challenges, then interrogating the subsequent interpretation of these provisions by the lower courts.

This article illustrates how these legislative protections have been rendered permeable through judicial interpretation. Judicial decisions have carved out a series of exceptions to the operation of ss. 276 and 278 . And even when these provisions are applied, their meaning has been transformed. It is largely because the courts have reduced these legislative protections to a narrow conception of privacy - one that is incapable of expressing the complex harms that inhere in sexual history cross-examination and access to confidential records - that complainants remain vulnerable to invasive credibility probing in sexual assault trials. Judicial decisions on sexual history and personal records applications produce a distinction between the "good victim" - a discursive construction whose idealized characteristics mimic the liberal legal subject entitled to privacy - and actual complainants. In the orchestrated gap between this idealized position and actual complainants, privacy becomes both fragile and illusive. The conclusion suggests a way forward. I contend that it is only by moving beyond privacy, by linking privacy with equality and by fully considering the individual and social consequences of sexual history evidence and records production that sexual assault complainants' access to justice can be improved.

\section{The Gendered Paradoxes of Privacy}

Elizabeth Schneider calls attention to the "dark and violent side of privacy" - to the ways in which privacy has permitted, encouraged and reinforced violence against women. ${ }^{15}$ Historically, male violence, especially within marriage, was untouched by law and protected

[1999] 3 S.C.R. $668[$ Miils].

[2000] 2 SCR 443, 2000 SCC 46 [Darrach].

Elizabeth Schneider, "The Violence of Privacy" (1990-1991) 23 Conn. L. Rev. 973 at 974 |Schneider, "Violence"]. Sec also: Reva B. Siegel, "'The Rulc of Love': Wife Beating as Prerogative and Privacy" (1995-1996) I05 Yale L. J. 2117 [Siegel, "Rule"]; Maria Bevacqua \& Carrie Baker, "'Pay No Altention to the Man Bchind the Curtain': Power, Privacy, and the Legal Regulation of Violence Against Women" (2004) 26:3/4 Women \& Politics 57; and Catharine A. MacKinnon, "Reflections on Sex Equality Under Law" (1991) 100 Yale L. J. 1281. 
as part of the private sphere of family life. In relation to sexual violence, this was most visibly apparent in marital rape exemptions that existed in most Anglo-American democracies until the 1970 s and 1980 s. $^{16}$ Yet it was not only in this most visible way that the constructed division between public and private withheld legal remedies to raped women. As Estrich has demonstrated, until fairly recently, only violent stranger rapes have been considered worthy of serious legal consideration, while the much more common situations of acquaintance rape have remained outside the realm of criminal legal intervention. ${ }^{17}$ The common law of rape, reproducing and reinforcing a definition of good victimhood linked to concepts of female propriety, chastity and modesty, effectively excluded all those exceeding this narrow construction from legal protection. ${ }^{1 x}$ Moreover, underlying the legal construction of rape, even in the present, is a view of sexual violence as a private, individual matter. Through its articulation in legal discourse, the systemic problem of sexual violence becomes individualized and contained in a moment. This individualized construction persists despite undeniable evidence of sexual assault as a dramatic and gendered social problem. ${ }^{19}$ Definitions of public and private are culturally constructed and shifting. Yet as feminist theorists have established, historically, the interrelationship between what is experienced as private and what is experienced as public is particularly complex in the area of gender, where the discourse of privacy has often served to mask violence, inequality and subordination.

The claim to privacy as a right is inescapably linked to the gendered history of the public/private distinction. Indeed, it has been argued that the "right of privacy was born not of woman, but of man." ${ }^{20}$ When Samuel D. Warren and Louis D. Brandeis penned their influential article "The Right to Privacy"21 in 1890, the right that they envisioned was firmly attached to the liberal/masculine individual. Still central in framing the contemporary legal interpretation of privacy, Warren and Brandeis argued for recognition of a common law right protecting the "inviolate personality" 22 of the individual, the "sacred precincts of private and domestic life"23 and the "robustness of thought and delicacy of feeling"2t in society. The

Bevacqua \& Baker, ibid. at 62. In Canada, until 1983, the crime of rape was defined as an act that occurs when a male person has sexual intercourse with a woman who is not his wife, and without her consent, thereby granting husbands spousal immunity (Elizabeth Comack \& Gillian Balfour. The Power to Criminalize: Violence, Inequality and the lan (Halifax: Femwond. 2004) at 111). For a review of the contemporary history of Canadian rape/sexual assault law reform, see Sheila Meintyre (with contibutions from Christine Boyle, Lee Lakeman \& Elizabeth Shechy). "Tracking and Resisting Backlash Against Equality Gains in Sexual Assault Law" (2000) 20:3 Canadiun Woman Studies 72 [Melntyre. "Tracking"]. Estrich, supra note 1. See also Bevacqua \& Baker, ibid. at 66.

Constance B. Backhouse, "Nineteenth-Century Canadian Rape Law 1800-92" in David H. Flaherty, ed., Essans in the History of Canadian Law, vol. 2 (Toronto: University of Toronto Press, 1983) at 200; Patricia L. N. Donat \& John D'Emilio, “A Feminist Redefinition of Rape and Sexual Assault: Historical Foundations and Change"(1992) 48:1 Journal of Social Issues 9.

Thirty-nine percent of Canadian women report at least one incident of sexual assault since the age of 16: there are also high rates of repeat experiences -42 percent of women reporting sexual attack and 57 percent of those reporting unwanled sexual touching reported two or more experiences (Holly Johnson \& Vincent F. Sacco, "Restarching violence against women: Statistics Canada"s nutional survey" (1995) 37 Can. J. Crim. 281 at 296). Anita L. Allen \& Erin Mack, "Ilow Privacy Got lts Gender" (1989-1990) 10 N. III. U.L. Rev. 441 at 441. 
Warren/Brandeis conception of privacy was firmly rooted in an individualist ontology, at a time when women were denied key dimensions of legal personhood and when the dominant ideology of separate spheres operated to deny individualism to women. ${ }^{25}$ This traditional conceptualization of the right to privacy, and the jurisprudential development that followed, first through the development of a privacy tort and later though judicial recognition of a constitutional right to privacy, ${ }^{26}$ emphasized an atomistic subject and sought to establish a zone around this subject, free from unwarranted state regulation and social interference. As Wendy Brown has argued, privacy's subject, the liberal individual, is a gendered subject, defined as one who is independent, autonomous and self-interested. This liberal subject is built upon and in opposition to characteristics, activities and responsibilities that have been socially and ideologically assigned to women - including dependence/interdependence, caring work and regard for others. ${ }^{27}$

The legal history of privacy recognition was at its heart distinctly gendered. ${ }^{28}$ For women, ideologically located in a private sphere viewed as man's castle, the protection of privacy emphasized not the entitlement to freedom and self-definition, but instead the protection of feminine modesty. Anita Allen and Erin Mack ${ }^{24}$ reveal the gendered image of the modest and secluded female informing such early American privacy precedents as DeMay v. Roberts ${ }^{30}$ and Union Pacific Raihway Company v. Botsford. If If for men privacy protected the exercise of liberal individualism, for women the legal claim to privacy amounted to the protection of traditional forms of femininity, not to the exercise of meaningful personal control or autonomy. Moreover, there was a persistent judicial refusal to "raise the curtain" around the home and "marital bedchamber" to "expose [them] to public curiosity" leaving women without legal recourse for injuries they experienced within these "private" spheres. 32

If historically, privacy for women was equated with the protection of feminine modesty, it is also clearly apparent that privacy's feminine subject was white. Rooted in slavery and the economic and sexual ownership of black women's bodies, African-American women were never afforded the same privacy as white women. In fact, the very construction of a white femininity tied to sexual propriety was accomplished in opposition to the myths of the

Allen \& Mack, stupra nole 20 at 446-53; Bevacqua \& Baker, supra nole 15 al 61.

Griswold1: Commecticul, 381 U.S. 479 (1965) (recognizing a constilutional right to privacy, establishing the marital bedrom as a zone of privacy and striking down a state law prohibiting contraception) [Griswold].

Wendy Brown, States of Injury: Pover and Freedom in Late Modernity (Princeton: Princeton University Press, 1995) at 156-58.

Allen \& Mack, supra note 20; Caraline Danielson. "The Gender of Privacy and the Embodied Self: Examining the Origins of the Right to Privacy in U.S. Law" (1999) 25 Feminist Studies 311.

Allen \& Mack, ibid:; set also Danielson, ibid.

DeMay v. Roberts. 9 N.W. 146 (Mich. Sup. Ct. 1881) (upholding action for invasion of privacy by presence of stranger in plaintilf s home during "sacred" time of childbirth).

Union Pacific Raihway. Company v. Botsford. 141 U.S. 250(1891) (referring to the "sacred" common law right to control one's person and refusing an order to submit a female plaintiff to a medical examination).

State v. Rhodes, 61 N.C. 453 (Sup. Ct. 1868) (declining to enforce an assault and batlery charge against a man who assaulted his wife on the grounds of the privacy of domestic relations "beeause the evil of publicity would be greater than the evil involved in the trifles complained of" at 454). For a discussion, see Siegel, “Rule," stupra notc Is at 2154-59. 
sexually promiscuous black woman and hypersexual black man. ${ }^{33}$ These sexualized/racialized myths, as critical race scholars have demonstrated, constituted powerful ideological supports for racial segregation in the Reconstruction era. ${ }^{34}$ Racialized constructions of proper femininity left black women outside the realm of privacy's tenuous protections, just as it rendered them vulnerable to sexual abuse and attack by white men. ${ }^{35}$ Through a parallel, if distinct, logic, Aboriginal women in Canada were rendered promiscuous and constructed as legitimate targets of sexual violence as part of the colonizing project. The portrayal of the Aboriginal woman as immoral and inherently sexualized helped to constitute and maintain the spatial and ideological boundaries between settlers and native peoples. As Sherene Razack has argued, from the nineteenth century, the almost universal conflation of the "squaw" with the prostitute placed Aboriginal women beyond the reach of law's protections. ${ }^{36}$

The historical right to privacy for women thus depended on the successful performance of propriety and modesty, coded as white, and tied to a protectionist rationale. Even later in the twentieth century, as reproductive freedom became one of the central focuses of privacy jurisprudence, the judicial emphasis was first on protecting the "marital bedroom" from public scrutiny, rather than securing decisional and reproductive autonomy for women. ${ }^{37}$ And in Roe $v$. Wade, ${ }^{3 k}$ a decision widely viewed as one of the greatest expansions of the right to privacy, a woman's decision to terminate her pregnancy was both medicalized and located under the guidance of a physician. ${ }^{39}$ By framing the abortion decision as "private," Roe also erased any consideration of the obligation of states to provide the conditions of access that would enable women to exercise autonomous choice." While not decided under the rubric of privacy but instead "security of the person," the Canadian Supreme Court's decision in $R$. v. Morgentalert2 nonetheless exhibited the same negative rights paradigm. In this important decision, striking down restrictions on abortion, a majority of the deciding judges emphasized how the Criminal Code erected unreasonable obstacles and delays, limiting access to a medically necessary service and violating the procedural aspects of fundamental

Sujata Moorti, Color of Rape: Gender and Race in Television's Public Spheres (Albany: State University of New York Press, 2002) at 55-57. 79: Maria Bevacqua. Rape on the Public Agenda. (Boston: Northeastern University Press, 2000) at 18-26.

Moorti, ibid. at 56; Bevacqua, ihid. at 24.

Bevacqua, ibid. at 23-26, analyzes African-American women's activism against the sexual violation of black women by white men and against lynching in the late nineteenth century, including the work of Ann Julian Cooper \& lda B. Wells.

Sherene H. Razack. "Gendered Racial Violence and Spatialized Justice: The Murder of Pamela George"

$(2000) 15$ C.J.L.S. 91 at 99.
Griswold, supra note 26 . For discussion, sec Schneider, "Violence", supra note 15 at 973-74.

Roe v. Wade, 410 U.S. 113 (1973) [Roe].

lbid. at 140 (the dilemma of abortion as a private dilemma to be resolved between a woman and her doctor). For discussion, see Deborah Nelson, "Beyond Privacy: Confessions Between a Woman and ller Doctor" (1999) 25 Feminist Studies 279; and Reva Siegel. "Reasoning from the Body: A Ilistorical Perspective on Ahortion Regulation and Questions of Equal Protection" (1991-1992) 44 Stan. L. Rev. 261 at $273-74$ [Sicgel, "Reasoning"].

Nadine Taub \& Elizabeth Schneider, "Women's Suburdination and the Rule of Law" in David Kairys. ed., The Politics of Law: A Progressive Critigue, rev. ed. (New York: Pantheon. 1990) isI at 157.60. Charter, supra note 5, s. 7 .

R. v. Morgentaler, [1988] 2 S.C.R. 30 [Morgenaler]. For a discussion see Sheilah L. Martin, "Abortion Litigation" in Radha Jhappan, ed., Women's Legal Stralegics in Canada (Toronto: University of Toronto, 2002) 335 . 
justice. Only one justice analyzed abortion restrictions in terms of women's rights to liberty and freedom of conscience. ${ }^{.3}$ None raised the importance of state provision of access to abortion services. ${ }^{44}$ This negativity renders the claim to privacy an unwieldy instrument for securing the provision of conditions that would enable meaningful control and autonomy.

The gendered history of privacy has given rise to robust and compelling feminist critiques. American feminist legal theorist Catharine A. Mackinnon has insisted that privacy very often amounts to a constitutionally protected "hellhole" for women. ${ }^{.5}$ As she writes:

In gendered light, the law's privacy is a sphere of sanctified isolation, impunity, and unaccountability. It surrounds the individual in his habitat. It belongs to the individual with power. Women have been accorded neither individuality nor power. Privacy follows those with power wherever they go.... When the person with privacy is having his privacy, the person without power is tacitly imagined to be consenting... If the woman needs something - say, cquality - to make these assumplions real, privacy law does nothing for her, and even idcologically undermines the state intervention that might provide the preconditions for its meaningful extrcise. ${ }^{46}$

Mackinnon expresses the key elements of the feminist critique of privacy rights. Privacy has been supported by a public/private division that has been oppressive to women. The claim to privacy is attached to the isolated individual, not the community; it has no social dimensions and thus lacks capacity to express collective interests in the struggle against gender and racial subordination. The right to privacy has been constructed negatively, precluding robust conceptualization of affirmative governmental obligation to provide the conditions necessary for decisional autonomy and self-determination. Finally, feminist critics have emphasized how privacy reinforces the idea that the personal and private are distinct from the social and political. As Schneider writes. "[p]rivacy encourages a focus on the individual and avoidance of collective definition, systemic analysis and social responsibility." ${ }^{\text {"7? }}$

It was this privatized and individualized construction of sexual violence that was taken up and challenged through the second wave feminist claim that "the personal is political." Beginning in the early 1970s, feminist activists in the anti-rape movement named the problem of sexual violence in a different way; they claimed that it was not a personal, individual problem, but instead, a systemic, political problem. ${ }^{49}$ Sexual assault, feminists

Morgentaler, ibid. at 162, Wilson J.

Michael Mandel, The Charter of Rights and the Legalization of Politics in Canada, rev. ed. (Toronto: Thompson, 1994) at 431-38 (arguing about the incompleteness of Morgentoler in securing meaningful reproductive autonomy for women).

Mackinnon, supra note 15 at 1311 . For other examples of the feminist critique of privacy, see Robin West. Progressive Coustitutionalism: Reconstructing the Fourteenth Amendment (Durham. N.C.: Duke University Press, 1994) at II8-24: Siegel, "Rule," supra note 15; Siegel, "Reasoning," supra note 39; Taub \& Schneider, supra note 40 at 154-57.

Mackinnon, ibid. at 1311 .

Schneider, "Violence," supra note 15 at 993.

For a discussion, see Donat \& D'Emilio, supra note 18; Bevacqua \& Baker, supra nole 15.

For an excellent activist analysis of the history and polities of the Canadian anti-rape movement see Lee Lakeman, Canada's Promises to Keep: The Charter and Violence Against Women (Vancouver: Canadian Association of Sexual Assault Centres, 2004). For an analysis of feminist anti-violence politics and the evolution of state responses see Lise Gotell, "A Critical Look at State Discourse on 'Violence 
insisted, must no longer be viewed as an outcome of sexual miscommunication. Feminists re-conceptualized sexual assault as stemming not from sexual passion, but instead from the desire to control and dominate. As Maria Bevacqua and Carrie Baker explain, "[f]ormulating rape as ... an abuse of power, shifts sexual assault from the private realm of desire and seduction to the public realm in which violent criminal activity is treated as such." Feminists sought recognition of sexual violence as a harmful, widespread and systemic practice that grows out of and works to reinforce male domination and female subordination. Based upon this political redefinition of rape as serious social problem, activists established a national network of rape crisis centres and demanded state action on a number of fronts, including law reform, social policy, public education and the provision of state funding for front-line work.

Over the 1980s and early 1990s, Canadian feminist activists experienced some success in gaining political recognition of sexual violence as a social problem and a legitimate site of state intervention. For a brief time, especially after the Montreal Massacre, ${ }^{\text {s1 }}$ governmental attention to "violence against women" provided an opportunity for the articulation of a broad array of feminist demands. Feminist activists achieved policy advances, particularly on the terrain of criminal law reform, and participated in innovative consultative forums with federal government actors. ${ }^{32}$ It was out of this period that that sexual assault law reforms, restricting access to sexual history evidence and confidential records and recognizing sexual violence as systemic, pervasive and gendered emerged.

This brings us to the final problematic dimension of privacy at issue in this rather sweeping review of the gendered paradoxes of privacy for sexual assault complainants that is, the re-privatization agenda underlying the neo-liberal state. If sexual violence was once, if even partially, redefined as public, not private, we are now witnessing the disappearance of sexual violence as a social problem and an object of public policy, and its containment within the frame of criminal law. These developments, as I have argued elsewhere, need to be set against the backdrop of the rise of the neo-liberal state. ${ }^{53}$ Under the

Against Women': Some Implications for Feminist Politics and Women's Citizenship" in Manon Tremblay \& Caroline Andrew, eds., Women and Polirical Represenation in Conodo (Ot1awn: University of Ottawa Press, 1998) 39 [Golell, "Critical"]. Bevacqua \& Baker, supra note 15 at 65 .

On 6 December 1989, Mare Lepine, entered an engineering building at the University of Montreal. ordered the men to leave and shot 14 young women to death, screaming that they were a "bunch of feminists." He then killed himself. In a note, he described the murders as a political act and blamed feminism for nining his life. In 199l, the federal government established December 6th as an annual National Day of Remembrance on Violence Against Women. For analysis of the policy impact of the Montreal Massacre see Andrea Levan. "Violence Against Women" in Janine Brodic, ed., Women and Canadian Public Policy (Toronto: Harcourt Brace, 1996) 319; and Gotell, "Critical," supra note 49.

:2 A broad-based consultation with feminist anti-violence activists preceded the 1992 sexual assault law reform. In 1994, the Department of Justice initiated yearly consultations with feminist activists on "violence against women," Funded by Justice, feminist activists and front-line workers set the agenda and delermined the participants. Feminist activists met for two days to establish key demands, after which meetings were held with both Cabinet minislers and bureaucrats. These consultalions were discontinued in 1998. For an analysis of these innovative consultative forums, see Sheila Mclntyre, "Feminist Movement in Law: Beyond Privileged and Privileging Theory" in Jhappan, supra note 42, 42 [Mclntyre, "Feminist"].

33 Lise Gotell, "The Discursive Disappearance of Sexual Violence: Feminist Law Reform, Judicial Resistance and Neo-liberal Sexual Citizenship" in Dorothy E. Chunn. Susan B. Boyd \& Hester Lessard, 
sway of globalization, the Canadian state's commitment to social citizenship has been eroding, replaced by economic efficiency and international competitiveness as the main objectives of government activity. Janine Brodie characterizes this transition in state form as "the great undoing," in which the market is elevated over the state, spaces of political contestation are narrowed, and social marginalization is intensified. ${ }^{54}$ Objects, once defined as sites of statc intervention, have been repositioned as private and individual, subject to selfgoverning and risk-managing citizens. These processes entail a reconfiguration of the gender order. Privatization and the erosion of social programs have increased women's labour and poverty, placing renewed emphasis on the responsibilized and privatized family as a site for the provision of once-public goods and services and on women's caring work within. ${ }^{55}$ Under new norms of citizenship, individuals are encouraged to conform to the norms of the market and to see themselves as active subjects responsible for enhancing their own well-being. ${ }^{56}$ By contrast, those who continue to make citizenship claims on the basis of structural disadvantage are increasingly cast outside the boundaries of legitimate public discourse. In "only a few years," Brodie insists, gender and the equality agenda have been virtually erased from public discourse and the formulation of policy.

In the present context, the recognition of sexual violence as a dramatic social problem has as all but disappeared. By 1998, yearly federal consultations on "violence against women" that had provided a window of influence for anti-rape activists within the federal policy process were dismantled. ${ }^{58}$ Feminist anti-violence activists were excluded from policy networks and systemic analyses of sexual violence were increasingly marginalized, replaced with de-gendered and individualized policy frameworks. One crucial institutional mechanism by which this has occurred is through the elaboration of victims' services bureaucracies within the federal and provincial states. ${ }^{39}$ In policy rhetoric, "violence against women" has been swallowed up by new de-gendered discourse of "victims' issues." In addition, the defunding of feminist front-line and activist work is a crucial aspect of this reconfigured context. ${ }^{(6)}$ But, of course, this vanishing act does not signal a victory over sexualized violence, merely its disappearance as an object of policy and public discourse.

All of these complexities condense in the analysis of privacy and sexual assault complainants under Canadian law. The complicated, paradoxical and gendered legacies of privacy influence judicial determinations on the admissibility of sexual history evidence and

34

eds., Feminism, Law and Social Change: (Re)Action and Resistance (2005) [unpublished, archived at University of British Columbia Press] [Gotell, "Discursive"].

Janine Brodie, "The Great Undoing: Stale Formation, Gender Politics, and Social Policy in Canada" in Catherine Kingfisher, ed., Western Welfare in Decline: Globalization and Women's Poverty (Philadelphia: University of Pennsylvania Press, 2002) 90 [Brodie, “Undoing”]: Janine Brodie, "MesoDiscourses, State Forms and the Gendering of Liberal-Democratic Citizenship" (1997) I Citizenship Studies 223 at 235 [Brodie, “Meso-Discourses"].

Ihid.; Judy Fudge \& Brenda Cossman, "Introduction: Privatization, Law and the Challenge to Feminism" in Brenda Cossman \& Judy Fudge, eds., Privatization. Law and the Chullenge to Feminism (Toronto: University of Toronto Press, 2002) 3.

Brodic, "Meso-Discourses," supra nole 54 at 237-39; David Garland, "'Governmentality" and the Problem of Crime: Foucauli, Criminology, Sociology" (1997) 1Theoretical Criminology 173 at 188. Brodic, "Undoing," supra note 54 at 91.

Mclntyre, "Feminist," supra note 52 at 80): Lakeman, supra note 49 at 24. Lakeman, ibid. at 127.

Ibid. at 111. 
access to confidential records. These legacies overshadow decisions about which complainants will be accorded protection against invasive credibility probing and about how much we need to know about any complainant in order for her to meet the test of credibility. Informing the outcome of judicial decisions on sexual history evidence and confidential records is a complainant's ability to approximate the characteristics of the (masculine) liberal legal subject, the subject whose individuality commands respect for a zone of freedom. As I will demonstrate, the idealized characteristics of this position combine within the privileged markers of neo-liberal citizenship to define the subject entitled to privacy as one who is fully rational, consistent and self-governing. The illusiveness of this subject position will be revealed by the many ways in which complainants can and do fall out from under this illusive standard; those who cannot demonstrate the rationality and consistency attached to this position fall through the gaps of legislative protection. The emptiness of privacy, its nothingness and negativity, when relied upon by courts to express concerns of sexual assault complainants, very often means that their needs will be subordinated to the rights of accused, viewed within the traditional framework of criminal law as more compelling and significant. Privatization, the shielding of intimate relations from legal regulation, continues to inhibit social and legal recognition of sexual violence as a serious social problem. And reprivatization within an era of neo-liberal governance has increasing transformed sexual violence from an object of political contestation into an issue of criminal law, privatized, individualized and depoliticized through this transformation.

\section{Legislative Restrictions on SeXUal History EvidenCE and Confidential Records: Contextual izing Privacy}

In 1992, in response to the Supreme Court's decision in R. v. Seaboyer ${ }^{\text {ol }}$ striking down restrictions on sexual history evidence as a violation of defendants' constitutional legal rights, the federal government re-enacted "rape shield provisions," yet in a weakened form that accorded with the majority's insistence on scope for judicial discretion. ${ }^{62}$ Largely due to feminist lobbying, Bill C- $49^{63}$ also sought to limit the traditional uses of sexual history evidence by reframing the Criminal Code's construction of consent and "mistaken belief in consent." The reform thus saw the enactment of a statutory definition of consent as voluntary agreement, ${ }^{6,4}$ the enumeration of situations of forced submission that do not constitute consent, ${ }^{65}$ limitations on the defence of mistaken belief in consent, as well as the requirement

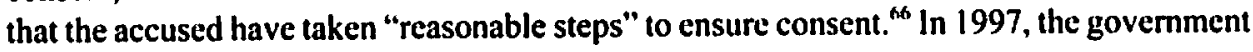

61 [1991] 2 S.C.R. 577 [Seaboyer].

62 CC, supra nole 7, s. 276.

63 An Act to amend the Criminal Code (sexual assaul). S.C. 1992, c. 38 [Bill C-49].

os Consent is defined as "the voluntary agreement of the complainant to engage in the sexual activity in question" (CC, supra note 7, s. 273(1)2).

CC, ihid., s. 273.1 (3) provides that

no consent is obtained, for the purposes of this section, if (a) the agreement is expressed by the words or conduct of a person other than the complainant: (b) the complainant is incapable of consenting to the activity; (c) the accused counsels or incites the complainant to engage in the activity by abusing a position of trust, power or authority; (d) the complainant expresses, by words or conduct, a lack of agreement to engage in the activity; or (c) the complainant, having consented to engage in sexual activity, expresses, by words or conduct, a lack of agreement to continue to engage in the activity.

It is not a defence to a charge under this section that the accused believed that the complainant 
again responded to feminist pressures through enacting Bill $C-46,{ }^{67}$ legislation addressing the widespread defence tactic of seeking access to complainants' personal records. ${ }^{88}$ This reform created a legislative regime regulating and restricting access, replacing the liberalized common law test that had been established by the Supreme Court in $R . v . O^{\prime}$ Connor. $^{69}$

These reforms can be viewed as textual residues of an era in which the "great undoing" that Brodie describes was developing unevenly, and in which, for a brief period, the interests of governmental and feminist actors converged around "violence against women" initiatives. Both legislative initiatives embedded recognition of sexual violence as a gendered and systemic problem, thereby challenging privatized and individualized constructions of sexual assault; both identified the complex harms that are implicated in unfettered crossexamination on sexual history and in records disclosure in a manner that extends well beyond a conception of privacy as the property of an individual. Bill C-49 and Bill C-46 gestured towards feminist discourses of sexualized violence in legislative preambles, recognizing the pervasiveness and gendered nature of sexual assault and the social objective of improving police reporting rates. Both preambles stated that "Parliament is gravely concerned about the incidence of sexual violence and abuse in Canadian society, and in particular, the prevalence of sexual violence against women and children." ${ }^{\text {"70 }}$ Both articulated the intention to ensure the full protection of equality rights alongside and in relation to legal rights. ${ }^{71}$ Bill C-46 framed this intent with the recognition that "violence has a particularly disadvantageous impact on the equal protection of women and children in society and on the rights of women and children to security of the person, privacy, and equal benefit of the law." 22 This preamble further expressed the need to fully protect the rights of those who are victims of sexual violence and in the event of conflicting rights, to accommodate and reconcile the rights of defendants and complainants. ${ }^{73}$ Both preambles expressed Parliament's desire to encourage the reporting of sexual offences, thereby exceeding an individual rights framework by identifying the social objectives underlying restrictions on sexual history and confidential

consented to the activity that forms the subject-matter of the charge if (a) the accused's belief arose from the accused's: (i) self-induced intoxication, or (ii) recklessness or wilful blindness; or (b) the accused did not take reasonable steps, in the circumstances known to the accused at the time, to ascertain that the complainant was consenting.

An Act to amend the Criminal Code (production of records in sexual offence proceedings), S.C. 1997, c. 30 [Bill C-46].

CC, supra note 7.

R. v. $O^{\prime}$ Connor, [1995] 4 S.C.R. 41 I [O' Comnor]. As many analysts have argued, the majorily opinion in $O^{\prime}$ Commor, laying out a two-stage common law test goveming production and disclosure, rested on a presumption of the de facto relevance of third-party records. Under the $O^{\prime}$ Connor regime, "likely relevance" functioned as a virtual "open door" through which judges were invited into the realm of the complainant's personal records. During the period between 1995 and 1997, records applications were a common feature of trials; records were nearly always determined "likely relevant" and produced to judges; and in 67 percent of decisions, records were disclosed to the accused (Karen Busby, "Third Party Records Cases Since R. v. O Connor" (2000) 27 Man. L.J. 355 at 356 [Busby. "Third"]). See also Steve Coughlan, "Complainants' Records After Mills: Same As It Ever Was" (2000) 33 C.R. (5th) 300; Jennifer Koshan, "Diselosure and Production in Sexual Violence Cases: Situating Silinchcombe," (2002) 40) Alta. L. Rev. 655; and Lise Gotell, "Colonization through Disclosure: Confidential Records, Sexual Assault Complainants and Canadian Law," (2001) 10 Social \& Legal Studies 315 [Gotell, "Colonization"].

Bill C-49, supra note 63; Bill C-46, supra note 67.

bid.

Bill C-46, supra note 67.

ibid. 
records. ${ }^{74}$ The preamble to Bill C-49 also stated Parliament's belief that "evidence of a complainant's sexual history will rarely be relevant and should be subjected to particular scrutiny."" The preamble to Bill C-46 enumerated the negative societal consequences of compelled records production in deterring complainants from seeking counselling and reporting to police, and for the work of those who provide services and assistance. ${ }^{76}$ Marked by processes of collective feminist mobilization preceding the 1992 and 1997 Criminal Code reforms, these preambles embedded feminist claims. They framed sexualized violence within gendered power relations, constructed sexual assault as a systemic social problem, gestured to the societal impact of judicial decisions and located these legislative changes within a concept of substantive equality.

Systemic understandings that were intended to guide the exercise of judicial discretion were also inserted into Criminal Code evidentiary provisions regulating sexual history evidence (s. 276) and access to confidential records (s. 278). These provisions require that such factors as discriminatory myths, the prejudicial impact on the trial process, the impact of decisions for police reporting rates, society's interest in the obtaining of treatment by complainants, and the equality and privacy rights of complainants be weighed against the legal rights of the accused in determining access to confidential records and the relevance of sexual history evidence." These provisions were clearly intended to compel judges to engage in a complex balancing exercise that extends beyond a narrow contest between the "privacy" of the individual complainant and the legal rights claims of individual defendants. Sections 276 and 278 recognized that much more is implicated in sexual history evidence and records production than simply confidentiality and informational privacy. When complainants are vulnerable to these mechanisms of credibility probing, women and children are deterred from making police reports, thus shielding sexual violence from criminal regulation and denying equal protection and benefit of the law. When interrogation on sexual history and on the contents of therapy, medical and other records is deployed to mobilize discriminatory constructions of sexual assault complainants, the equality rights of all women and children are diminished. These provisions, in effect, contemplate a contextual analysis of sexual history and records applications at trial - an analysis in which the individual rights of complainants and defendants are set against the backdrop of sexual violence as a serious social problem and framed by a recognition of the need to curtail the circulation of discriminatory myths within sexual assault trials.

\section{The Permeability of Restrictions on Sexual History Evidence: and Confidential Records: When Privacy is not Enougi}

\section{A. Perceptions of 1990s LaW Reforms and the Case Law THAT FORMS THE BASIS FOR THIS ANALYSIS}

Criminal defence lawyers insist that 1990s sexual assault law reforms have politicized sexual assault trials, severely eroding the legal rights of the accused. In an article in The 
Lawyer's Weekly published in 1992, one defence lawyer went so far as to label Bill C-49 "an expression of feminist hatred." ${ }^{.78}$ The Canadian Council of Criminal Defence Lawyers and the Criminal Lawyers Association argued that the balancing of interests proposed by new provisions regulating confidential records would restrict relevant evidence and obliterate the right to a fair trial. ${ }^{79}$ An article in the Criminal Lawyers Association newsletter following Mills emphasized the importance of reasserting legal rights against the privacy interests of complainants:

\begin{abstract}
What is portrayed as an invasion of the complainan's privacy is in reality an essential tool in the appropriate casc to ensure that a person accused of a serious charge of sexual assault receive a fair trial. The importance of pursuing these types of applications, when appropriate, cannot be overstated.... When applying for the production of third party records, defence counsel should be relentless in reminding the courts that "it can never be in the interests of justice for the accused to be denicd the right to make full answer and defence" [quotation from Mills majority].
\end{abstract}

Based on interviews conducted with Manitoba defence lawyers in the late 1990s, Elizabeth Comack and Gillian Balfour found widespread agreement that sexual assault law reforms had pushed the pendulum much too far in favour of complainants' rights. ${ }^{81}$ This view of $1990 \mathrm{~s}$ law reforms as "politically motivated" and contrary to the principles of fundamental justice, as Comack and Balfour suggest, has precipitated the adoption of defence strategies aimed at defying and subverting the legislative reforms. ${ }^{82}$

Far from the picture that emerges in the rhetoric of criminal defence lawyers, however, legislative restrictions on sexual history evidence and confidential records appear to operate less as an inviolable shield around complainants and more as a permeable sieve. In the assessment of judges, Crown attorneys, defence lawyers and complainant advocates interviewed by Renate Mohr in 2002, 1990s law reforms have produced a marginal improvement in complainants' experiences; yet, these actors agree that the trial remains "very unpleasant," "humiliating" and "embarrassing," or a "nightmare" for complainants. ${ }^{83}$ These legal actors reported that sexual history evidence, when requested, is often determined to be admissible; and even when applications were unsuccessful, unless the judge preempts the questioning, the complainant is often subjected to at least some cross-examination on her history. ${ }^{8.4}$ Moreover there is a widespread perception among defence attomeys that sexual history is most often relevant, while Crown prosecutors expressed the view that defence

Rob Martin, "Proposed sex assault Bill an expression of feminist hatred" The Lanyers Weekly 11:36 (31 January 1992) 9 at 9.

Mills, supra note 13 (Factum of the Intervener Canadian Council of Criminal Defence Lawyers); Mils, ibid. (Factum of the Intervener Criminal Lawsyers Association (Onturio)).

Steven Skurka \& Elsa Renzella. "Delending a Sexual Assault Case: Third Party Record Production," (2000) 21:2 For the Defence 32 (QL).

Comack \& Balfour, stupra note 16 at 117-18. Sec also Renate Mohr, '“Words are not Enough' Sexual Assault, Legislation, Education and Information" Bill C.49 amd C.46 Key Informam Study (Ottawa: Department of Justice, 2002) (in-house repon citcd with permission, on file with author). As this study also reperts, defence counsel expressed serious concem that the balance has been tipped so far in favour of the complainant that the accused's right to a fair trial has been jeopardized (at 4).

Comack \& Balfour, ibid. at II8.

Mohr, supra note 81 at 14.

lbid, at 12-13. 
counsel "makes it relevant." records may have functioned to stem rising tide of records applications and to prevent "fishing expeditions" by defence, ${ }^{86}$ most legal actors perceived that records when requested are often produced to judges and that partial disclosure to defence is sometimes ordered. ${ }^{87}$

The case law analysis that forms the basis for this article echoes the findings of Mohr's study. As part of a larger project assessing the complex impacts of 1990 s sexual assault law reforms, l examined: 22 lower court decisions concerning the admissibility of sexual history evidence in the three year period following the Supreme Court decision in Darrach (released 12 October 2000) (see Appendix A), and 37 lower court decisions concerning access to complainant records in the three year period following the Supreme Court decision in Mills (released 25 November 1999) (see Appendix B). ${ }^{88}$ This research revealed that where sexual history applications were made, there was high rate of defence success -53 percent. Similarly, in 48 percent of cases in which a complainant's personal records were sought, production of at least some records was ordered. ${ }^{84}$ These rates of admissibility and production suggest that statutory regimes regulating sexual history evidence (s. 276) and access to complainants' records (s. 278) have both been rendered permeable through judicial interpretation.

Previous research has suggested that certain categories of complainants, especially women and children who have been extensively documented and those who have visible sexual histories may be most at risk. This includes: children under the care of child welfare authorities; women with mental health histories or disabilities; Aboriginal women; racialized women; women who work in the sex trade; and women who have made other allegations of sexual assault." In the case law analysis undertaken for this research, it was not possible to see how these patterns of heightened vulnerability are manifested. Most often, very little information is provided about complainants beyond the story of the alleged assault. As Jennifer Koshan has also emphasized in her review of post-Mills records cases, "very few

libid.

Ibid. at 14-15; Koshan also emphasizes how one of the most positive implications of $s .278$ has been a marked reduction in the number of records applications. supra note 69 at 674.

Mohr, ibid. at 14-18.

All cases were found through searches on the Quicklaw legal database (C.J. (iroup Source).

In most cases that I have analyzed, all that is available is a decision about whether records pass the threshold test for production to the judge. Only five cases dealt with the question of disclosure to the accused. I have not dealt with these decisions specifically, but I have included them in my analysis of likely relevance. In one case, the record produced was not disclosed: R. v. W.P.N., [2000] N.W.T.J. No. 15,2000 NWTSC 22 (QL) [W.P.N.]. In four cases, some or all records, or portions thereof were disclosed: $R$. v. Hammond (2002), 53 W.C.B. (2d) 475 (Ont. Ct. J.) (decided on basis that there was not "reasonable expectation of privacy") [Hammond]; R. v. W.G. (2000), 46 W.C.B. (2d) 20 (Nlld. S.C.(T.D.)) [W.G.]; R. v. L.P.M., [2000] O.J. No. 4076 (Sup. C. J.) (QL) [L.P.M.]; R. v. W.C., [1999] M.J. No 542 (Q.B.) (QL). There are too few disclosure decisions among the cases analyzed to reach any conclusions about emerging legal trends. Koshan's unalysis of $\$ 278$ cases, in which she found a production rate of $14 / 30$ in trial level decisions, also cmphasized how many decisions do not make it clear whether records ordered produced to the court were subsequently disclosed to the accused (supra note 69 at $677-78$ ).

Marilyn T. MacCrimmon \& Christine Boyle, "Equality, Faimess and Relevance: Disclosure of Therapists Records in Sexual Assault Trials" in Marilyn T. MacCrimmon \& Monique Ouellette, eds. Fihering and Analyzing Evidence in an Age of Diversity (Ottawa: Canadian Institute for the Administration of Justice, 1993) at 81. 
[decisions] indicate whether the complainant is from a racial minority, is disabled, or is otherwise disadvantaged. ${ }^{.91}$ In the discursive economy of judicial decisions, complainants are decontextualized from the complex power relations that render them vulnerable to sexual violence and then to defence practices of creditability probing and disqualification. ${ }^{92}$

While much about complainants is obscured in the text of these decisions, two themes become apparent in the decisions analyzed here. First, all of these cases involved defendants who had personal or professional relationships with the complainants. Among the allegations at issue were sexual assaults by boyfriends, spouses/ex-spouses, relatives, family friends or acquaintances, as well as sexual assaults by a range of authority figures, including a religious leader, a doctor, a therapist, a probation officer and a group home leader. It is not surprising that there were no cases of "stranger rape" within the decisions analyzed. In part, this merely reflects the statistical likelihood ( 80 percent) that complainants will know their assailants. ${ }^{93}$ Crucially, it is personal and often intimate knowledge about the complainant (for example, that she has sought therapy or that she has made other allegations of sexual assault) that enables defendants in these cases to assert the relevance of sexual history or confidential records evidence.

Second, it is evident from these decisions that many complainants are, or were at the time of the alleged assault, vulnerable children. Almost 90 percent of the allegations at issue in the post-Mills cases were of sexual offences, often historic, against children or adolescents. It is both surprising and troubling that in 35 percent of post-Darrach cases analyzed, the sexual history evidence that was sought involved child or adolescent complainants under the legal age of consent at the time of the alleged assault. The frequency with which both areas of case law deal with historic abuse claims and with contemporary assault claims made by children/adolescents implies that these allegations are regarded with particular suspicion in law, necessitating external corroboration. Moreover, as the following analysis will demonstrate, complainants who may have been subjected to repeated victimization and who have been known to make other allegations of abuse, often find their histories of sexual coercion opened to the court.

As my analysis of the post-Mills and post-Darrach case law will demonstrate, there is strong judicial resistance to the feminist-inspired features of the 1990s law reforms. An interrogation of lower court decision making reveals how judges have narrowed the reach of ss. 276 and 278, carving out a series of exceptions to their application, thereby avoiding the complex balancing of individual and social concerns that these provisions envision. And when these provisions are engaged and considered, it is paradoxically not that judges ignore

There is strong evidence that racialized women and women with disabilities face dramatic rates of sexual violence. Front-line organizations conlirm that racist and sexist altitudes toward Aboriginal women continue to make them vulnerable to sexual assaults in Canadian citics (Amnesty Intemational, Stolen Sisters: A Human Rights Response to Discrimination and Violence Against Indigenous Women in Cancola, 2004, online: Amnesty <www.amnesty.ca/resource_centre/reports/view.php? load=arcview \&article $=1895 \& \mathrm{~d}=$ Resouree + Centre+Repons $>$ ). Eighty-three percent of women with disabilities will be sexually assaulted during their lifetime (Metropolitan Action Committee on Violence against Women and Children. Statistic Sheet: Serual Assaut (Toronto: METRAC, 2005), online: <www. metrac.org/new/stat_sex.htm $>$ [METRAC]). 
the privacy interests of complainants, but instead complainant and societal interests are reduced to a narrow and unelaborated conception of privacy. In effect, the gendered paradoxes of privacy are deeply implicated in the recent case law on sexual history evidence and access to confidential records.

\section{B. The Millos and DarRaCh Decisions: Emphasizing Privacy and Privileging Legal. Rigits}

The permeability of ss. 276 and 278 is rooted in the Supreme Court decisions in Darrach and Mills. These decisions, while widely regarded as feminist victories, are highly ambiguous. The decisions confirmed the constitutionality of statutory regimes set in place by 1990s law reforms and at the same time weakened their meaning." In upholding ss. 276 and 278 in Mills and Darrach, the Supreme Court did move away from its earlier and narrow focus on the accused-state dyad as the only relevant constitutional relationship in sexual assault law. In both decisions, the Court recognized that legal rights of the accused must not be allowed to distort the "truth-seeking" function of the trial process by employing discriminatory myths about rape victims." In effect, the decisions advanced a position that a fair trial is one that does justice to all parties, including the complainant. Yet the Supreme Court's gestures to a broader conception of fair trial rights, incorporating both complainants' equality rights and societal concerns, were tempered by the framing of complainants' claims through a narrow conception of privacy.

The disclosure of confidential information in the context of sexual assault trials, as the Mills ruling emphasized, inevitably infringes on the privacy rights of the complainant, which the Court locates within the right to be protected against "unreasonable search and seizure." 96 Privacy is defined here negatively as the "interest in being lef alone by that state" and the right to "control the dissemination of confidential information." ${ }^{.97}$ To the extent that the value of this negative space is justified by the Court, it is in abstract and liberal terms, as being necessary for the protection of "dignity, integrity and autonomy." sustained discussion of the specific harms that arise from records disclosure is in its acknowledgement of how, in the particular context of therapeutic relationships, privacy is essential for trust and where confidentiality is threatened, so too is the complainant's mental integrity and security of the person. ${ }^{49}$ Beyond acknowledging the importance of therapeutic confidentiality, however, what drives the majority's analysis is a highly individualistic and atomistic understanding of complainants' concerns. These concerns are defined primarily in terms of the right to own one's storics. This kind of analysis conceives the complainant as an isolated individual, not caught up in a web of power relationships that influence her ability to construct authoritative versions of events.

Gotell, "Colonization," supra note 69 at 339-40; Coughlan, supra note 69 at 301; Koshan. supra note 69 at 669-71, 672-74.

45 Mills, supres note 13 at paras. 74, 90; Darrach, supra note 14 at para. 37.

* Charter, supra note 5, s. 8.

47 Mills, supra note 13 at para. 80.

9s Jbid. at para 81 .

Sobid. at paras. $82-85$. 
Darrach is a briefer and more economical decision that is heavily reliant on the arguments of the Mills majority. In Darrach, the Court offered only passing references to equality and located the interests of complainants within a completely unelaborated conception of privacy rights. ${ }^{100}$

The Supreme Court's narrow framing of ss. 276 and 278 set the tone for an excision of societal and systemic concerns from the balancing exercises that these provisions set out. Again and again, the Mills and Darrach decisions stressed that these statutory provisions are constitutional because they emphasize and retain judicial discretion. ${ }^{101} \mathrm{~A}$ central feature of both provisions, as I have demonstrated, was their enumeration of a series of considerations that are meant to define the scope and exercise of judicial discretion when ruling on the admissibility of sexual history and defence access to records. As a mark of feminist influence on the shaping of ss. 276 and 278 , both provisions require the courts to take into account factors that extend beyond the narrow and individualized contest between the privacy of complainants and the fair trial rights of the accused, including equality rights and the dignity of complainants, the sway of discriminatory myths and the impact on reporting rates. Yet these systemic and contextual considerations were rendered marginal in these Supreme Court decisions. In Mills, the majority transformed the considerations enumerated in s. 278.2(3) into a "check-list of the various factors that may come into play during a judge's deliberation." ${ }^{102}$ Through this judicial sleight of hand, the multiple considerations identified in $\mathbf{s .} 278$ were reconstructed as optional factors, which need not be analyzed in deciding on the production and disclosure of personal records. ${ }^{103}$ In Darrach, there was absolutely no discussion of the considerations listed in s. 276(3), which are intended to frame the judicial analysis of whether the introduction of sexual history evidence at trial would be more prejudicial than probative. The only factor specifically articulated by the Court was the requirement to take into account the "right of the accused to make full answer and defence." 104

In fact, both decisions worked to privilege defendants' rights, undermining the Court's recognition of a broad conception of fundamental justice. In a move that arguably eroded the very thrust of ss. 276 and 278 , the majority in Mills insisted that where there is any doubt about the likely relevance of the records judges should err on the side of production. ${ }^{105} \mathrm{Cited}$ with approval in Darrach, ${ }^{106}$ this judicial privileging of fair trial rights within the balancing exercises established by the 1990 s sexual assault reforms effectively redefines their very meaning. Far from constituting unqualified feminist victories, the Mills and Darrach decisions foreshadow and permit lower court resistance to the systemic and contextual aspects of these feminist-inspired reforms.

Darrach, supra note 14 at paras. $3,28$.

Ibid. at para. 120; Mills, supra note 13 at para. 37 . Christopher P. Manfredi contends that it was primarily the emphasis on judicial discretion with in these legislative protections for complainants that determined the Court's findings of their constitutionality (Christopher P. Manfredi, Feminist Activism in the Supreme Court: Legal Mobilization and the Women's Legal Education and Action Fund (Vancouver: University of British Columbia Press, 2004) at 148); sec also Koshan, supra note 69 at 673. Mills, supra note 13 at para. 134.

Coughlan, supra note 69 at 306. See also Koshan, supra note 69 at 673.

Darrach, stupra note 14 at para. 43.

Mills, supra note 13 at para. 134.

Darrach, supra note 14 at para. 42. 


\section{Preventing "Fishing ExPeditions": Lower COURT Decisions ON RECORDS APPLICATIONS AND THE NECESSITY OF A CASE-SPECIFIC EvidentIaRY FOUNDATION}

In her analysis of judicial responses to the 1990s sexual assault law reforms, Sheila McIntyre concludes that criminal law may be "incorrigible under present circumstances;" she insists that the individuated norms of criminal law are deeply resistant to the recognition of substantive equality and to acknowledging the "collectivized realities of systemic privilege and dispossession. ${ }^{10 \%}$ it may appear that 1 am embracing an equally pessimistic interpretation. The decisions analyzed here, however, embed a contradictory set of logics that often constrain, and yet sometimes may also enable, the recognition of complainant rights. The dichotomy between specific and general assertions of the relevance of records is one such enabling space within the Supreme Court decision in Mills. The Court's insistence on the necessity of a case-specific informational foundation to ground a finding of the "likely relevance" of personal records ${ }^{108}$ has had a positive impact for complainants. Indeed, largely because of this insistence, there is a reduced likelihood of production of records in the post1999 case law. ${ }^{109}$ In cases examined in which records do not pass the threshold for production, judges relied heavily on the Mills requirement of "case-specific evidence" that would raise an assertion of likely relevance from the level of the general to the specific. $R$. $\nu$. Batte, ${ }^{110}$ for example, is a complex historical abuse case, which is widely cited as an authority on the application of the case-specific evidence criteria. Citing Mills, the Batte decision finds that simply because a complainant

said something about a matter which could be the subject of cross-examination at trial, does not raise a reasonable possibility that the complainant's statement will have some probative value."I

An accused must point to some "case specific evidence or information" to justify that assertion. In my view, an accused must be able to point to something in the record ... that suggests that the records contain information which is not already available to the defence. ${ }^{12}$

The Batte requirement that something in the record must constitute new and otherwise unavailable information establishes a high threshold test for likely relevance, ${ }^{113}$ which is used in several post-Mills cases to deny production. ${ }^{1 / 4}$ Such decisions are important in shrouding complainants from speculative production requests ("fishing expeditions") that were the

107 Mclntyre, "Tracking," supra note 16 at 79.

108 Mills, supra note 13 at para. 118.

109 As Busby's research on the pre-Mills case law demonstrated, almost 67 percent (24/35) of records applications passed $O$ 'Connor's relaxed threshold test for production to the judge. My analysis revealed a 48 percent production rate in post-Mills decisions (Busby, "Third," supra note 69 at 383 ).

Ihid. at para. 77.

lbid. at para. 75.

The threshold for "likely relevance" must be met before records are produced to the judgt. For a description of the two-step procedure laid out in s. 278, sec supra note 8.

lif Sec: R. v. D.M. (2000), 49 W.C.B. (2d) 217 (Ont. Sup. Ct. J.) at para. 37; R. v. P.J.S., [2000] Y.J. No. 119,2000 YTSC 23 at para. 26 (QL) [P.J.S.]; $R$. v. Sutherland (2001), 156 C.C.C. (3d) 264, 2002 NSSC 49 at para. 13 ; R. v. D.W.L. (2001), 156 C.C.C. (3d) 152,2001 NSCA 111 at para. $26[D . W . L] ;$.$R . v.$ M.G. (2001), 49 W.C.B. (2d) 171 (Man. Prov. Ct.) at para. 19 [M.G.]; R. v. Thompson (2001), 52 O.R. (3d) 779 (C.A.) at para. 6 [Thompson]; R. v. S.P., [2001] O.J. No. 2898 (Sup. Ct. J.) at para. 10 (QL). 
norm under the $O^{\prime}$ Connor regime. ${ }^{115}$ This may constitute the single most positive implication of s. 278. ${ }^{116}$ Yet as Koshan points out, even the Batte requirement constitutes a double-edged sword for complainants. The thrust of the ruling is that if evidence can be accessed through cross-examination of the complainant at trial, the threshold for production of records to the court will not be met. As Koshan warns, "[t]his may encourage defence counsel to engage in intense and invasive cross-examination.""117

\section{Carving Out Exceptions: General/Specific, SeXual/Non-SeXual AND SEXUAl History EVIdenCE}

An analogous general/specific dichotomy in relation to sexual history has had far more complex and less positive implications for lower court interpretations. Section 276(1)(a) specifies that "no evidence may be adduced unless it is of specific instances of sexual activity." inference that because of sexual activity, a complainant is "more likely to have consented" and "less worthy of belief" - the so-called "twin myths" (s. 276(1)). ${ }^{119}$ As emphasized by the Supreme Court in Darrach, however, s. 276 is not a "blanket exclusion" and only prohibits the use of sexual history evidence when it supports these twin myths. ${ }^{120}$ According to the Court's interpretation, this provision "excludes all discriminatory generalizations about a complainant's disposition to consent or about her credibility based on the sexual nature of her past sexual activity." 21 The Court here sets out a pair of linked and unstable binaries general/specific, sexual/non-sexual - that, in turn, create tensions in lower court interpretation.

In situating the purpose of s. 276 exclusively in the eradication of "discriminatory generalizations" based upon "the twin myths," the Supreme Court set the stage for an extremely narrow reading of this provision. According to this interpretation, sexual history evidence may be used to support specific, but not general, inferences on issues of consent and credibility. ${ }^{122}$ This interpretation has found some support in the lower courts. ${ }^{123}$ In $R . v$. Temerizoglou, for example, a general/specific distinction was used to ground the admission of evidence used to show the development of a "more than platonic" relationship between a young nanny and older male defendant, "notwithstanding an age difference," in order to

Iis Gotell, "Colonization," supra note 69 at 327-29.

116 Mohr's study reinforces this point. She found very strong agreement among legal actors that s. 278 has succeeded in discouraging "fishing expeditions" by the defence, supra note 81 at 19.

$117 \quad$ Koshan, supra note 69 at 678.

118 CC, supra note 7, s. 276.

119 Ibid.

120 Darrach, supra note 14 at para. 32.

121 lbid. at para. 34 [emphasis in original].

122 This interpretation of s. 276 was proposed by David M. Paciocco as the only interpretation consistent with the legal rights of the accused (David M. Paciocco, "Competing Constitutional Rights In An Age of Deference: A Bad Time To Be Accused" (2001) 14 Sup. Ct. L. Rev. (2d) I 12). Paciocco has been a vehement critic of legal protections for complainants. R.J. Delisle contends that the Court in Darrach adopts Paccioco's approach (R.J. Delisle, “Adoption, Sub-silentio, of the Paciocco Solution to Rape Shicld Laws" (2001) 36 C.R. (5th) 254).

123 R. v. B.W.E. (2002), 55 W.C.B. (2d) 240, 2002 SKPC 82 [Ehrstein]; R. v. Temertzoglou (2002), 56 W.C.B. (2d) 184 (Ont. Sup. Ct. J.) [Temertzoglou]. 
make a consent defence plausible. ${ }^{124}$ Of course, such "specific" inferences are inescapably tied to the "generalized" assumption that consent to intercourse is more likely when there has been a relationship of previous physical contact. To interpret s. 276 based upon impermissible "general" rationales and permissible "specific" rationales has the potential to severely weaken its protections. ${ }^{125}$

The general/specific dichotomy is related to the assertion of a distinction between sexual/non-sexual that is a pivotal axis within judicial assessments of the scope and reach of s. 276. In Darrach, the Supreme Court restated its arguments in $R$. v. Crosby, ${ }^{126}$ affirming that sexual history evidence can be introduced for its "non-sexual features," including to show inconsistent statements or a pattern of fabrication, or to rebut Crown evidence. ${ }^{127}$ This series of exceptions rests on an arbitrary distinction between what is and what is not sexual. The impact of this sexual/non-sexual distinction is to invite defence to introduce sexual history evidence on the basis of its non-sexual features - but these non-sexual features are always framed by symbolically gendered sexual evidence.

The rebuttal exception has, of course, long been a feature of sexual history jurisprudence. ${ }^{128}$ Yet what is striking about the post-Darrach case law is just how elastic this exception has become. In several decisions, sexual history evidence was sought on the basis of its "non sexual" features to: contradict physical evidence of child sexual assault;" ${ }^{29}$ refute the complainant's testimony that he/she was a virgin at the time of the alleged assault; ${ }^{130}$ demonstrate confusion between perpetrators; ${ }^{131}$ account for sexual knowledge of a child complainant; ${ }^{132}$ and to show a pattern of fabrication. ${ }^{133}$ In some of these decisions, evidence that is inescapably sexual was determined admissible on the basis that it is not sexual. ${ }^{134}$ In the appellate decision in $R$. v. R.A., for example, a complainant's claim to have been assaulted by six men other than the accused was ruled admissible. The court determined that because this evidence was sought to show a pattern of fabrication, it was not excluded by s. 276: "The fact that the prior activity is sexual in nature is not relevant; it is the tale surrounding the alleged prior sexual activity that is relative to a relevant issue - the credibility of the complainant." 135 Through this slippery justification (in other words, that stories of sexual coercion can be rendered non-sexual through their translation into words).

13: Susan M. Chapman, "Section 276 of the Criminal Code and the Admissibility of 'Sexual Activity' Evidence" (1999-2000) 25 Queen's L.J. 121 at 143.

127 Darrach, supra note 14 at paras. 35-36.

128 Chapman, supra note 125 at $165-67$.

18. R. v D.A.K., [2001] Q.J. No. 6170 (C.Q. (Crim. \& Pen. Div.)) (QL) (nuled admissible) |D.A.K.]. 58 W.C.B. (2d) 288, 2003 NSSC 157 (partially admissible) [Lak)]. 
the appellate court permitted evidence based upon the discriminatory assumption that those with histories of victimization have a tendency to make false allegations. ${ }^{136}$

The defence strategy of seeking sexual history on the basis of its non-sexual features and the support for this strategy within post-Darrach judicial interpretation enables judges to determine admissibility without ever engaging in the balancing exercise set out in s. 276 (3). When evidence is sought to show complainant inconsistency or to rebut Crown evidence it may be determined admissible without consideration of how the myth-ridden rationales grounding such requests may "arouse ... prejudice," "introduce ... discriminatory belief," affect "reporting rates," and compromise a complainant's right to "privacy," "personal security" and the "full protection and benefit of the law" (s. $276(3))$. The loophole provided by the sexual/non-sexual distinction illustrates how judicial interpretation has undermined the legislative scheme for assessing the admissibility of sexual history.

\section{E. Carving Out Exceptions: Personal Records and the “Reasonable" Expectation of Privacy}

If the interlinked distinctions between general/specific and sexual/non-sexual have provided mechanisms for limiting the reach of s. 276, the scope of s. 278 has been constrained through judicial interpretation of the "reasonable expectation of privacy." In some post-Mills cases, records are disclosed to the accused because they are found to fall outside the regime established by s. 278. Many of these cases are decided on the basis that because records contain statements to persons in authority with the expectation that this would cause authorities to investigate and act in some manner, there is thus no "reasonable expectation of privacy" in the records. ${ }^{137}$ It has been confirmed, for example, that complainants have "no reasonable expectation of privacy" in criminal injury compensation claims because of the public nature of these proceedings. ${ }^{138}$ In R. v. K.A.G., letters to school officials describing allegations against a fellow student were also deemed to fall outside the expectation of privacy. ${ }^{139}$ More troubling than the exclusion of records clearly related to the allegations at issue was the decision in Hammond, ${ }^{140}$ here it was decided that police investigative reports about an unrelated complaint should be disclosed to the accused. The court ruled that the s. 278 regime did not apply. Even though the police reports were of a completely separate incident, they were ordered released to the accused under the Crown's disclosure obligations. ${ }^{141}$ That the accused sought to use these records on the basis of an unsubstantiated claim that they might establish a pattern of making false complaints is not subjected to any rigorous judicial analysis. The issue whether the disclosure of these

136 Other decisions have aflirmed, however, that unless the complainant has recanted or other allegations are demonstrably false, evidence sought for the purpose of showing a propensity to make "false allegations" is inadmissible (Porter, supra note 131 at para. 3); R. v. N.P., [2001] O.J. No. 1825 at para. 28 (Sup. Ct. J.) (QL) [N.P.]; and R. v. S.A., [2002] O.J. No. 1218 at para. 11 (Ct. J.) (QL) [S.A.]. See R. v. K.A.G. (2001), 192 N.S.R. (2d) 5, 2001 NSFC I at para. 8 [K.A.G.].

R. v. L.S. [2000] O.J. No. 3991 (Sup. C. J.) (QL).

K.A.G., supra note 137.

Hammond, supra nole 89.

Ibid. at paras. 13-16. These obligations were established in R. v. Stinchcombe, [199|] 3. S.C.R. 326. In this decision, the majority articulated a strong and expansive interpretation of accused's rights under ss. 7 and 11 (d) of the Charfer and on this foundation broadened the Crown's obligation of disclosure to include all information relevant to the defence. 
unrelated police reports would introduce bias into the trial or rely on discriminatory myths was never undertaken. As the deciding judge concluded, drawing on Mills, though sidestepping s. 278, "uncertainty should be resolved in favour of the accused."142

Judicial avoidance of the legislative regime set in place by s. 278 is also starkly illustrated in the Supreme Court decision in $R$. $v$. Shearing. ${ }^{143}$ This case involved multiple allegations of historical sexual offences against the leader of a quasi-religious cult. Shearing is a complicated case, raising issues not only about the scope of s. 278 , but also about similar fact evidence and proper limits on cross examination. Most relevant to this discussion was the question of whether the diary of one of the adult women complainants, who, as a child, had lived with the accused, was covered by the $\mathrm{s}$. 278 regime. This diary, kept for a brief period in 1970 during the alleged offences, had been left behind by the complainant when she had moved out 22 years before the trial. During the trial, the diary had fallen into the hands of the accused who sought to cross-examine the complainant on her failure to record the alleged abuse.

In a seven-to-two decision on this question, the Supreme Court curtly dismissed the applicability of s. 278 to the diary. Rejecting the claim that the diary should be returned to the complainant so that the accused could make an application for disclosure, the majority argued colloquially that this "would seem ... to shut the barn door after the horse has escaped."144 While Binnie J. goes to great lengths to uncouple privacy from property rights in his analysis, the conflation of privacy with possession nonetheless remains in his conclusion. ${ }^{145}$ As he states: "The simple fact is that the defence had possession of the diary. It was not engaged in a "fishing expedition." $1+6$ In this manner, the majority diminishes the complainant's significant interests in controlling the circulation and uses of her diary, arguing, in essence, that because violation of her privacy rights had already occurred and because the diary was already in the possession of the defence, the proper question was not disclosure but admissibility. ${ }^{177}$ As noted by Koshan, the effect of this interpretation could be to encourage defendants to acquire records by improper means. ${ }^{148}$

On question of admissibility, the majority ruled that 'the nature and scope of KWG's diary did not raise privacy or other concerns of such importance as to 'substantially outweigh' the appellant's fair trial right to cross-examine on the diary (both the selected entries permitted by the trial judge and the absence of entries)." ${ }^{149}$ Here, cven the slanted balancing of rights envisioned by Mills, is avoided in a decision that arguably reinvents the doctrine of recent complaint. ${ }^{150}$ Underlying the majority's analysis is a construction of a good rape victim, who behaves in certain ways. If victim records her daily life in a diary, then it is expected that she will record incidents of abuse. In the end, what Shearing tells us is that it is not only what

142 Hammond, ibid at para. 27.

143 R. v. Shearing, [2002] 3 S.C.R. 33, 2002 SCC 58.

is Ibid. at para. 90; L'Hieureux-Dubi J. and Gonthier J. dissenting on this issue at paras. 154-86.

its bid.

14t Mid. at para. 96.

147 lbid. at para. 105.

143 Supra nole 69 at 674-75.

149 Shearing, supra note 143 at para. 150.

150 L'Heureux-Dube J., for the dissent, argues that 'the assumption that 'silence speaks volumes' is unfounded, and by itself cannot lead to the conclusion that no assault occurred" (ibid. at para. 174). 
complainants have said and written about their assaults that can be opened to legal invasion, it is also what is not said and not written.

\title{
F. JUdicial TRANSFORMATION OF THE BALANCING EXERCISES CONTEMPLATED BY SECTIONS 276 AND 278: REDUCING OF COMPLAINANTS' INTERESTS TO PRIVACY
}

As I have demonstrated, judicial decisions often sidestep the protections offered by $\mathbf{s s .} 276$ and 278 by carving out exceptions to their applicability. Yet even in cases where judges take into account the factors laid out in ss. 276(3) and 278.2(3), the resulting analysis is most often cursory. ${ }^{\text {sI }}$ Judges will usually simply review the facts of the case, summarize defence submissions, recite the provisions of s. 276 or s. 278 , and then render a decision without ever showing their actual reasoning. ${ }^{152}$ The following example is illustrative:

\begin{abstract}
I have carefully considered the factors set out in section 276(3). 1 lind that it is in the interests of justice to permit the admission of the evidence as it could potentially lead the jury to conclude that the complainant's allegations as to what occurred are not credible. I am satisfied that the exclusion of this evidence from the jury would preclude the accused from making full answer and delenee to the offence charged.... [O]ther fuctors referred to in section $276(3)$, including the issues of the personal dignity, the privacy rights of the complainant and society's interests in encouraging reporting of sexual assaults do not...trump the accused's right to make full answer and defence. ${ }^{153}$
\end{abstract}

Even though ss. 276 and 278 ask judges to weigh defendants' legal rights against the privacy and equality rights of complainants and to consider such factors as "discriminatory myths" and society's interest in police reporting and in ensuring counselling for complainants, rarely are any concerns other than privacy and legal rights acknowledged or analyzed. Furthermore, the construction of complainants' and defendants rights' as being in competition, with legal rights necessarily prevailing, embraces a hierarchical approach to rights and ignores how fair trials should be fair to complainants.

In light of the feminist-inspired and multi-dimensional balancing exercises contemplated by ss. 276 and 278 , it is remarkable how very few evidentiary decisions relied on an equality analysis or raise concerns about how the contents of records or evidence of sexual history might detract from the faimess of the trial process by introducing discriminatory myths. In $R$. v. Tatchell, , $^{\text {st }}$ where residential school records were sought for a "blind," "developmentally delayed" complainant, the court cautioned that the application may be based on "the discriminatory belief or bias that all persons with an intellectual disability ... are potentially incapable of telling the truth" and suggested that the release of such records would discourage reporting by those with "intellectual disabilities." ${ }^{\text {ISS }}$ In R. v. N.P., evidence

131 Sec also: Mclntyre, "Tracking," supra note 16 at 75; Colin Meredith, Renate Mohr \& Rosemary Cairns Way, Implententation Review' of Bill C-49 (Ottawa: Department of Justice, 1997), online: Department of Justice Canada <http://canada.justice.gc.ca/cn/ps/rs/rep//997/tr97-1a.html>.

19: Koshan also observed the paucity of judicial reasoning in her analysis of production orders (supra note 69 at 682).

133 Toms, supra note 130 at para. 21.

1s. (200I), 207 Nild. \& P.E.I.R. 131 (S.C.(T.D.)) [Tatchell].

195 Ibid. at paras. 20-22. 
of a sexual relationship between an adolescent girl and her boyfriend was sought in order to pursue a theory that she had lied about her father's sexual abuse to escape parental control. This evidence was ruled inadmissible on the basis that it would inevitably introduce "discriminatory myths" into the trial process. As the decision states: "From these allegations, a jury could well find that a 15 year old girl who is sexually active is somehow less believable." ${ }^{156}$ In R. v. K.K., ${ }^{157}$ applications for the disclosure of counselling records and for admission of sexual history evidence were denied on the basis of "discriminatory myths" and the "danger of prejudice." In this case, concerning allegations of historical sexual assault, the defence initiated ss. 276 and 278 applications in order to suggest the possibility of confusion between the alleged assault and an earlier incident of sexual abuse. While rejecting the $s .276$ application on the basis of the failure to establish a case-specific evidentiary foundation, the deciding judge ruled that evidence of other allegations of sexual abuse would infringe on the complainant's equality, dignity and privacy and arouse prejudice, if disclosed to the jury. ${ }^{158}$

Such decisions are noteworthy, however, only as exceptions. Overall, the post-Mills and post-Darrach decisions analyzed here are marked by persistent judicial refusals to consider the complex concerns implicated within sexual history evidence and access to personal records. In contrast to statutory language and intent, the contest between privacy and fair trial rights, conceived in a zero-sum manner, becomes the only focus of judicial analysis. The judicial reframing of ss. 276 and 278 represents a reassertion of individualized analysis as the only legitimate framework of criminal law. This is evident, not only in narrow judicial analysis of these provisions, but also, at times, in overt resistance. According to the Court in $R$. v. R.B., for example: "Counseling services should certainly continue to encourage people who are suffering from abuse to continue to be counseled. In the large scale of the criminal justice system one cannot remove the right to make full answer and defence because some victims may not avail [themselves] of counseling. This is only one factor which a judge should consider in a review under s. 278.1."159

The lower courts appear to follow Mills and Darrach in holding that the rights of the accused must prevail when there are doubts about ordering production or allowing crossexamination on sexual history. ${ }^{\left({ }^{(k)}\right)}$ Set against this judicial privileging of fair trial rights, the

N.P., supra note 136 at para. 15.

K.K., supra note 131.

lbid. at paras. 44-45.

R. v. R.B. (2002), 214 Nild. \& P.E.I.R. 216 (S.C.(T.D.)) at para. 33 [R.B.]. See also Temertzoglou, supra note 123 at para. 31 . We might wonder why more such trial rulings are not appealed, given that judgments like R.B. clearly misinterpret and improperly apply s. 278. As Koshan suggests, based upon her own experience as a Crown prosecutor, "the practical demands upon the Crown" prevent this actor from being the guardian of complainant interests (supra note 69 at 684). Moreover, as she has found, at least with respect $10 \mathrm{~s} .278$ rulings, the appellate level courts display a high level of deference to trial judges (at 679). Equally signilicant in explaining the apparent failure of Crown prosecutors to appeal such rulings is surprising degrec of ignorance about the intent and content of' ss. 276 and 278. Mohr's study, for example, found that very few legal actors, including Crowns, were even aware of the preambles of $C-49$ and $C-46$ and seemed surprised that the provisions disect judges to consider the equality interests of complainants (supra note 81 ).

Sec, for example: Temertzoglou, ibid. at para. 23; Toms, supra note 130 at pura. 21 . Sec the follewing records decisions: Hammond, supra note 89 at para. 23; R. v. D.P.F. (2001), 199 Nfld. \& P.E.I.R. 224 (S.C.(T.D.)) at para. 36 [D.P.F.]; R. v. L.G.. [2000] O.J. No. 5090 (Sup. Ct.) at paras. 76, 85 (QL) [L.G.]: and R. v. C.S. (2000), 195 Nfld. \& P.E.I.R 104 (S.C.(T.D.)) at para. 17 [C.S.]. Koshan also notes the judicial privileging of fair trial rights in her analyses of s. 278 decision making (supra note 69 at 684). 
individualized framework of privacy rights provides only tenuous protection against defence strategies of seeking access to personal records or sexual history. Most decisions frame the protection of records and the restriction of sexual history as primarily and sometimes exclusively a matter of "privacy."161 The complexities of systemic sexual violence and questions of the relative authority of claims about coercive sexuality disappear within this individualized discourse of privacy. One explicit example of this narrow judicial focus is $R$. $v$. Clifford ${ }^{162}$ a case in which counselling records were sought in order to provide foundation for the claim that a "religious" complainant felt "shame" because of her sexual relationship with the accused and had therefore lied to protect her "reputation." Ignoring its broader purposes, the Ontario Court of Appeal characterized the intention of s. 278 as exclusively the protection of privacy. The decision relies on the traditional liberal framework of privacy as the sole rationale for restrictions on records: "The point of these provisions is that the complainant has the right to be left alone in these highly personal areas unless the accused can meet the test set out by Parliament."163

Section 276 has also been reconstructed through a myopic judicial emphasis on privacy. And lurking just underneath judicial constructions of privacy in these decisions are traces of the gendered legacy of privacy. Echoing the early privacy precedents discussed above, decisions on admissibility sometimes rely heavily on concepts of "humiliation" and "embarrassment." In effect, an emphasis on feminine modesty weaves through these decisions, sometimes providing justification for admissibility of sexual history evidence. Some judges define the harms of sexual history based upon a scale of sexual activity in which evidence of sexual intercourse is viewed as the most serious threat to privacy, while evidence of sexual touching is depicted as having only a marginal impact on privacy. In $R$. v. R.H.B, for example, cross-examination of a 13-year-old girl on whether she had rubbed against an adult male defendant when she was wearing only a towel was defined as "minimal sexual content" and therefore characterized as being "of minor concern in relation to the privacy rights of the complainant." defence claim that because "the prior sexual activity is of a much less intrusive nature than the activity that forms the subject matter of the charge ... the potential prejudice to Ms. M.C.'s personal dignity is lessened."165 Aside from reviving a penetrative standard that was at the discursive centre of the old rape law rejected in the early 1980s, this line of interpretation decontextualizes the harms of sexual history evidence from the context of women's/girls' social and sexual subordination. Being interrogated about one's sexual experiences is indeed "humiliating"; yet this conceptualization ignores how sexual history evidence has the effect of reinforcing discriminatory assumptions and disqualifying claims of violation. Residing underneath the legal rationale in R.H.B., for example, is the promiscuous adolescent girl as a Lolita-like temptress; informing Temertzoglou is the young

161 The following records cases cite no consideration but privacy: $R$. v. Clifford (2002), 58 O.R. (3d) 257 (C.A.) at para. 51 [Clifford]; Thompson, supra note 114 at para. 3; and W.P.N., stupra note 89 at para. 4. In some cases, other considerations such as "equality" or society's interest in reporting are simply listed. but never elaboruted and the primary emphasis remains on "privacy" unconnected to uny other concerns (D.W.L., supres nole 114 at para. 37: P.J.S., supra note 113 at paras. 8-9; and M.G. supra note 114 at paras. 14-15). libid. lbid. at para. 52. R. v. R.H.B. (2002), 162 B.C.A.C. 107,2002 BCCA 1 [R.H.B.]. Temertzoglou, supra note 123 at 33 . 
woman whose claim is rendered suspect by the existence of previous "non-platonic" contact with the accused.

The judicial focus on privacy thus encourages a legal analysis that is decontextualized, obscuring the circulation of discriminatory myths. Privacy is constructed as an abstract good, apart from any consideration of the consequences of defence access to complainants' records and sexual history. Underpinning the emphasis on privacy is a highly atomistic understanding of complainants' concerns, defined primarily in terms of the right to "own one's stories" and to be protected from "embarrassment." Janine Benedet argues that the use of sexual history evidence is not wrong because it constitutes an invasion of privacy, but instead because it undermines sexual equality. ${ }^{166}$ While even equality arguments may not provide a framework capable of expressing the complexities of records production and the admission of sexual history, they could permit a fuller analysis of assumptions that inform these tactics. An equality analysis would demand attention to sexual violence as a systemic practice and to how sexual history evidence and confidential records are deployed to reinforce gendered constructions of those who complain of sexual assault as mendacious, vindictive, hysterical and inherently suspect. These constructions constitute a gendering strategy whose reach extends beyond privacy as the property of an individual.

\section{G. The Fragility of Privacy: "Ideal Victim"}

\section{vS. ACTUAL COMPLAINANTS}

Separated from the kind of contextual analysis contemplated by ss. 276 and 278, the lonely shield of privacy often appears to provide only fragile protection against invasive credibility probing by defence. When complainants can be constructed as failing to meet the requisites of the "ideal rape victim," their privacy rights are often dismissed and discounted. Weaving through these decisions is the discursive production of the "ideal victim," a symbolic and unreal construct, who serves as the measure of any real complainant's credibility. ${ }^{167}$ Inferences based upon sexual history and upon the presumed content of personal records are used to create a distinction between the complainant and the "ideal victim." If once the "ideal victim" was defined primarily by her sexual morality, increasingly the new good victim is also marked by her/his consistency and rationality. ${ }^{16 \%}$ The characteristics of this "ideal victim," in effect, bear striking resemblance to the privileged markers of neo-liberal citizenship. As Elizabeth Comack and Tracey Peter have recently argued, the "ideal victim" is essentially one who lives up to the neo-liberal ethos: she is rational, responsible, and demonstrates that she can make the "right" choices in her own selfgovernance. ${ }^{169}$ To claim privacy rights, one must be able to: assume the standpoint of the responsibilized neo-liberal subject; articulate a consistent account that appears capable (most often at an early stage in the trial process) of meeting the test of legal "Truth"; and squeeze the complex ambiguities of coercive heterosex into the binary, individuated logic of the

Janine Benedt, "Legal Rights in the Supreme Court of Canada in 2000: Secing the 'Big Pieture."” (2001) 14 Sup. Ct. L. Rev. (2d) 97 at 107.

Larcombe, supra note 2.

Ibid. at 144.

Elizabeth Comack \& Tracey Peter, "How the Criminal Justice System Responds to Sexual Assault Survivors: The Slippage between "Responsibilization' and 'Blaming the Victim" [unpublished, forthcoming in C.J.W.L. in 2006] copy on file with author, cited with permission. 
consent/coercion dichotomy. Complainants who can be represented as failing to meet standards of consistency, rationality and psychological coherence risk losing the protections afforded by privacy rights.

The "ideal victim" marks the case law on access to personal records. Defence rationales and judicial justifications for production and disclosure of therapy records most often rely on the construction of "actual complainants" as hysterical, deluded and manipulated. In five of nine cases in which the production and sometimes disclosure of "all or most" records was ordered, ${ }^{170}$ the rationale grounding the order was that the complainant(s) suffered from "false memory syndrome" (FMS). " FMS is a "syndromized" category, forged initially by parents claiming they had been "falsely" accused of abuse. ${ }^{172}$ It is without status as a recognized psychological disorder. Yet it has increasingly gained legal legitimation. ${ }^{173}$

In many of these cases, even the "typical" characteristics associated with FMS (the recovery of long-forgotten memories and "memory-shaping" therapeutic techniques) are notably absent. As Elizabeth Sheehy has also observed, there is considerable "slippage" in the case law between the definition of FMS and its application by judges and lawyers. FMS is used to discredit large categories of complainants, while very few recover memories in therapy. As Sheehy observes, "'[f]alse memory' attacks are launched against women simply because they have used therapists, whether or not they ever 'forgot' the rapes, and even in cases where the rape was not historic, but happened only months earlier."174 Sheehy's observations are applicable to this set of decisions as well; R. v.R.B. ${ }^{175}$ is one stark example. This case concerned an adult woman's allegations of contemporary sexual assault against her ex-spouse. Defence used statements made at the preliminary inquiry (where the complainant admitted to having flashbacks of childhood abuse, taking anti-depressants and undergoing counselling) as the basis for a theory of FMS. The trial judge, in turn, ordered production of all therapeutic records, both because counselling had occurred before the complaint was laid

Here I am making a distinction between cases in which some records are produced and those in which all or most are produced. In $27 / 37$ cases conceming records that I analyzed, there was a decision on the production and/or disclosure of records. In 13/27 cases, as least some records were produced to the judge. In nine cases, however, all or mosi reconds were ordered produced.

See C.S., supra note 160; L.G., supra note 160; R. v. G.P.J.. [2001] 6 W.W.R. 734, 2001 MBCA I8 [G.P.J.]; R.B., supro note 159; W.G., supra note 89. The rationale, where elaborated, for production/disclosure in the other cases included: a finding of no reasonable expectation of privacy (K.A.G., supra note 136), inconsistent statements (L.P.M., supra note 89), and the ability of a developmentally disabled complainant to perceive and recall events $(R . v . D . H .(2000), 258$ A.R. 346, 2000 ABPC 20).

Susan M. Vella, "Recovered Traumatic Memory in Historical Childhood Sexual Abuse Cases: Credibility on Trial" (1998) 32 U.B.C. L. Rev. 91 at 92 and n. 5:

F.M.S. is a plirase which has been coined by a private American non-profit organization ... [it] describe[s] a condition whereby a patient (usually female) has been influeneed, through suggestions made by her therapist, into genuinely believing she was the victim of historical childhood sexual abuse when the alleged sexual abuse never in fact occurred... . This Foundation primarily consists of parents who have been accused of sexual assault by their children and includes a small number of women who have recanted their allegations of sexual assault against their parents. 
and because "[t]he complainant's recall of events is clearly an issue at trial and a review of the procedures followed concerning her memory and the techniques used, may well be relevant and probative." 176 This order was made despite the fact that there was no evidence that this allegation was based on recovered memories. In fact, the preliminary record shows the complainant emphatically denying this assertion: "Well when you got the fellow you've been going out with and the father of your two kids for fifteen ycar[s] on you, assaulting you and you're having a flashback of your father putting a gun to your mother's head, yes, I think I can separate the difference." 17

A parallel set of rationales weaves through the case law on sexual history. These decisions reveal a welcome reluctance to make generalized links between sexual experience, credibility and consent. As I have argued elsewhere, there is evidence of increasing judicial acceptance of a specific consent standard in recent case law. ${ }^{178}$ After the Supreme Court rejected the use of the implied consent defence in $R . v$. Ewanchuk, ${ }^{179}$ trial judges have more strictly applied the consent provisions of the Criminal Code, interpreting consent as clear words or actions signifying agreement to engage in specific sexual activity and requiring defendants to take positive steps to secure agreement. ${ }^{180}$ These developments have made it more difficult to link past sexual experiences with consent. In the cases analyzed for this article, however, evidence of non-consensual sexual history is very often at issue. In several of these cases, defence attempted to use allegations of past assaults to show: a pattern of fabrication; ${ }^{181}$ inconsistent statements; ${ }^{182}$ a complainant's proneness to exaggeration; ${ }^{183}$ faulty memory; ${ }^{184}$ and confusion about perpetrators. ${ }^{185}$ As Sheehy has also argued, prior victimization is increasingly deployed to undermine a complainant's testimony by suggesting that "she was damaged by prior trauma such that she is an unreliable witness who may have imagined additional assaults; even if she was assaulted she may be confused and thus mistaken as to who injured her; her earlier rape allegations were not substantiated such that her current disclosure is tainted by her earlier statements." defence assertions that allegations are the product of fantasy or maliciousness work to hystericize complainants, creating a gap between actual complainants and the idealized rational victim entitled to the protections afforded by privacy rights.

Statistics Canada's Violence Against Women Survey found a dramatically high incidence of sexual assault ( 39 percent), as well as disturbingly high rates of repeat experiences: 42 percent of women reporting sexual attack and 57 percent of those reporting unwanted sexual

Ibid. at para. 29 . See also paras. $27,28,30,34$.

lbid. at para 21.

Gotell. "Disappearance," supra note 53.

R. v. Ewanciuk, [1999] I S.C.R. 330.

Gotell, "Disappearance," supra note 53. In this article, I review the post-Ewanchuk case law. My analysis is based upon 48 decisions rendered between 1999 and early 2004. In order to gain a sense of tsends in the judicial interpretation of consent and mistaken belief, I made the decision to analyze casts from four provincial jurisdictions: British Columbia ( 11 decisions): Alberta (nine decisions); Ontario (23 decisions); and Newfoundland (four decisions).

R.A., supra note 133; S.A., supra note 136.

Lalo, supra note 130.

D.S., supra nole 134.

Porter, supra nole 131.

K.K., supra nole 131 ; N.P., supra note 136.

Shechy, supra note 173 at 172. 
touching, reported two or more experiences ${ }^{187}$ Against this strong evidence of sexual violence as gendered, pervasive and repetitive, judicial discourses cling to and reinforce the individuated frame of criminal law. Where complainants' narratives challenge a liberal legalistic and rigidly individualized construction of sexual assault, they may be most vulnerable to disclosure of records, cross-examination on sexual history, and to the ultimate disqualification of their claims. This is apparent in cases in which the pervasiveness of sexualized coercion within a complainant's own life renders her crazy and unstable, prone to fabrication and unable to distinguish between reality and fantasy. Simply by inferences attached to prior victimization, complainants are hystericized, constructed as the very antithesis of the rational legal subject. Judicial hostility to social and political analyses of sexualized coercion is also revealed in cases where complainants acknowledge a reinterpretation of their past in light of new knowledge about the pervasiveness of sexual violence and its devastating consequences. In $R . v . W . G .,^{188}$ for example, an adult male complainant laid a charge of historical sexual abuse after reading the report of an inquiry into sexual abuse by clergy, which in his words, "made him aware of the severity of child sexual abuse." This revelation provided the crucial element in a theory of FMS, leading to the disclosure of several years of counselling records.

Some decisions also reinforce the view that complainants are highly suggestible and vulnerable to delusions induced by therapists. In R. v. G.P.J., ${ }^{190}$ the view of feminist therapy as inherently manipulative grounded an appellate decision upholding an acquittal and an order for the production and disclosure to the accused of 12 years of therapy records. Here the complainant alleged that she had been repeatedly raped by her brother-in-law between the ages of 11 and 21. Time after time, the appellate court raised the possibility of memory manipulation, owing to the complainant's testimony that she was "getting more memory ... [o]f the things that happened."191 It is not simply coincidental that the agency where she received therapy was a feminist agency that counselled women. Statements made by the complainant during trial influenced by feminist understandings of sexual violence were used to support the disclosure order and in the end, to destroy her credibility. She had, for example, used terms like "victimized," talked about it being a "natural thing" for sexual abuse victims to see themselves as being in love with their abusers, and testified that she had learned this from other sexual abuse victims. ${ }^{192}$ Feminist therapy was constructed as being intrinsically manipulative and justifying defence access to records. Relying on the fact that the complainant alleged repeated forced intercourse yet had never become pregnant, the appeal judge found that credibility was at issue. As he stated, her credibility was at issue because "of the bizarre tale of sexual abuse that she related. It was a story that at times challenged believability." 193

The "unbelievability" of this complainant's story seems to lie, at least in part, in its reliance on feminist analyses of sexualized coercion. Trial and appellate level decisions on 
sexual history and records production reveal clear evidence of judicial resistance to the innovative and feminist-inspired features of ss. 276 and 278. The extension of criminal law beyond the narrow and traditional concern with the legal rights of defendants is largely thwarted through these decisions, tempered only by the recognition of complainants' interests in an individualized paradigm of privacy. Broader concerns with the reproduction of conservative sexual ideologies in sexual assault law or with women's unwillingness to report to police are erased. Underpinning these decisions is the discursively reconstructed "ideal victim," who is no longer defined simply by her sexual propriety and morality; she is also rational, demonstrates psychological coherence and tells a story that coincides with the individuated narrative of criminal law. It is this "ideal victim," built upon the narrow characteristics of the liberal legal subject and neo-liberal citizen, who constitutes the standard for claiming privacy in sexual assault trials. The narrowness of this idealized subject, the frequency with which actual complainants fail in their performance of idealized victimhood and the emptiness and negativity of the claim to privacy combine to render women and children vulnerable to having their consensual and coercive sexual experiences and personal records interrogated at trial.

\section{CONCluSION: CONSEQUENCES AND THE Necessity of Contextualizing Privacy}

As I have demonstrated, complainants remain vulnerable to defence practices of sexual history interrogation and confidential records disclosure. It is crucial to recognize how scrutiny of sexual history evidence and information obtained through personal records has both individual and societal implications. These legal practices do indeed result in the violation of complainants' privacy interests. But as I have argued here, the implications extend beyond the individualized framework used by judicial actors to assess the admissibility of sexual history evidence and the relevance of confidential records. Underlying sexual history evidence and the use of therapy and other records in the context of sexual assault trials are a variety of old and new rape myths. The mobilization of these discriminatory myths enables defence counsel to construct complainants as hysterical, unstable, manipulated, deluded and/or vindictive. The circulation of such discriminatory myths inhibits the legal recognition and punishment of sexual violence, distorting and undermining the "truth seeking" function of the trial process. What Andrew E. Taslitz has called the "courtroom rituals of degradation and exclusion" within sexual assault trials deny women as a group equal protection and inhibit women's equal participation in the justice system. ${ }^{194}$

These trial practices also continue to deter women from reporting sexual assaults. A survey of sexual assault survivors conducted in 1998 revealed that concern over the possibility of records disclosure was a major reason for not reporting - " $[w]$ omen said that they were unwilling to risk being re-victimized by 'being put under a microscope during the trial." "195 A national survey of sexual assault centres (conducted in 2005 as part of our

195 Tina Hatlem, Survey of Sexual Assauh Survivors: Report to Participants (Ottawa: Department of Justice, 2000 ) at 9. 
broader research project) confirmed that the threat of records disclosure and sexual history interrogation continues deter police reporting. ${ }^{196}$ When sexual violence is pervasive and police reporting rates remain the lowest of any violent crime ( 8 percent), ${ }^{197}$ women's access to justice is severely and negatively impacted.

Judicial resistance to the contextual frameworks put in place by ss. 276 and 278 of the Criminal Code, as I have suggested, prevents legal recognition of the complex concerns implicated in sexual history evidence and access to confidential records. The narrow and individualized interpretation of privacy rights informing judicial decisions fails to provide an analytic framework capable of expressing the societal dimensions of these practices. But there is also another peril of privacy that is suggested here - the peril of depoliticization. The threat of sexual history interrogation and the disclosure of confidential records works to inhibit social and legal recognition of sexualized violence by constructing the private as the only legitimate realm for reflection. It is only within the boundaries of "privacy" that women and children can tell and own their stories of sexual violation. If feminists broke the silence around sexualized violence in the last part of the twentieth century, we could say that in the current period is one where a new silence is being re-established. Underlying the probing of complainants' sexual histories and records is the message that we need to be very careful about what we say about sexual assault. Discourses about sexual violence, once breaking into public discourse, are increasingly being re-privatized.

For those of us concerned about sexual violence as a social problem and about the treatment of complainants at trial, it is clear that the assertion of privacy as a legal and discursive strategy is both incomplete and contradictory. The gendered paradoxes of privacy weave through the recent case law on sexual history evidence and access to confidential records. As I have argued, however, the legislative regimes put in place by the 1990s law reforms transcend the individualized focus on the privacy rights of complainants and the legal rights of defendants. The systemic, societal and equality-enhancing rationales of these law reforms, articulated in legislative preambles, need to fully inform judicial interpretation. A contextual approach to weighing the rights of the accused and the rights of complainants is clearly contemplated within the text and wording of ss. 276 and 278 of the Criminal Code. A contextualized analysis of sexual history and personal records applications cannot stop with privacy. Judicial analysis must also explore how the violation of privacy enables the circulation of discriminatory myths in sexual assault trials, diminishes the equality rights of

Lise Gotell, Barbara Crow \& Melanie Beres, "National Survey of Sexual Assault Centres: Preliminary Analysis of Results," [unpublished 2005, copy on file with author]. A mail-out questionnaire was sent to a national sample of Canadian rape crisis and sexual assault centres. Finy-three centres ( 45 percent of total sample) responded. Eighty-five percent reported that survivors remain very concerned about the possibility of their sexual history being raised at trial, with some groups (including those who have had a previous sexual relationship with the perpetrator, sex trade workers, Aboriginal women and lesbian women) having heightened concerns. Survivors contacting centres are less concemed about the possibility of their records being disclosed, with 47 percent of centres reporing that survivors are concerned about this possibility. In a series of questions assessing centres' pereeptions of why survivors do not make police reports, however, there was strong agreement that the possibility of retords disclosure is a significant factor. "Distrust of the criminal justice system" was also a significant factor affecting the decision to make a police report. 
women and children and inhibits the important social objective of bringing sexual violence to the attention of the criminal justice system.

Obstacles to the development of such an approach are, however, significant. Interrogation of recent sexual assault case law reveals how statutory regimes regulating access to sexual history and complainant records have been eroded, rendering complainants vulnerable to hystericization and disqualification. Judicial discourses have reasserted and reconstituted the individualizing frame of criminal law against feminist, contextualized constructions of sexual violence as gendered and systemic. To embrace a contextualized analysis linking privacy and equality, would deeply unsettle the individuated norms of criminal legal discourse. John McInnes and Christine Boyle have observed that the simple "suggestion that gender equality is relevant to the delineation of the rights of an accused person, or to the assessment of the relevance of evidence, sets one apart as a hysterical crusader, rather than a responsible and thorough advocate." ${ }^{198} \mathrm{But}$, as I suggest here, a radical reorientation of judicial interpretation, one that would transform the equality advocate from a "hysterical crusader" into a thoughtful proponent of equal justice and fair trial rights, is urgently needed. 


\section{APPendix A: Post-Mills Cases Analyzed (37)}

R. v. B.(E.) (2002), 57 O.R. (3d) 741 (C.A.)

R. v. Batte (2000), 49 O.R. (3d) 321 (C.A.)

R. v. C.S. (2000), 195 Nfld. \& P.E.I.R 104 (Nfld. S.C. (T.D.))

R. v. D.H. (2000), 258 A.R. 346, 2000 ABPC 20 (Youth Div.)

R. v. D.M. (2000), 49 W.C.B. (2d) 217 (Ont. Sup. Ct.)

R. v. D.P.F. (2000), 194 Nfld. \& P.E.I.R. 51 (Nfld. S.C. (T.D.))

R. v. D.P.F. (2001), 199 Nfld. \& P.E.I.R. 219 (Nfld. S.C. (T.D.))

R. v. D.P.F. (2001), 199 Nfld. \& P.E.I.R. 224 (Nfld. S.C. (T.D.))

R. v. D.W.L. (2001), 156 C.C.C. (3d) 152, 2001 NSCA 111

R. v. E.A.N. (2000), 45 W.C.B. (2d) 267,2000 BCCA 61

R. v. G.P.J., [2001] 6 W.W.R. 734, 2001 MBCA 18

R. v. Hammond (2002), 53 W.C.B. (2d) 475 (Ont. Ct. J.)

R. v. Howorko (2002), 54 W.C.B. (2d) 304 (Alta. C.A.)

R. v. Hudson, [2001] O.J. No. 5456 (Sup. Ct. J.) (QL)

R. v. K.A.G. (2001), 192 N.S.R. (2d) 5, 2001 NSFC 1

R. v. Kasook, [2001] 2 W.W.R. 683, 2000 NWTSC 33

R. v. L.G., [2000] O.J. No. 5090 (Sup. Ct. J.) (QL)

R. v. L.P.M., [2000] O.J. No. 4076 (Sup. Ct. J.) (QL)

R. v. L.S., [2000] O.J. No. 3991 (Sup. Ct. J.) (QL)

R. v. Lalo (2002), 207 N.S.R. (2d) 227, 2002 NSSC 49

R. v. M.A.S., (2000), 48 W.C.B. (2d) $171,2000 \mathrm{MBQB} 189$

R. v. M.G. (2001), 49 W.C.B. (2d) 171 (Man. Prov. Ct.)

R. v. N.P., [2001] O.J. No. 1828 (Sup. Ct. J.) (QL)

R. v. P.E. (2000), 45 W.C.B. (2d) 371 (Ont. C.A.)

R. v. P.J.S., [2000] Y.J. No. 119, 2000 YTSC 23 (QL)

R. v. Perry, [2000] O.J. No. 2112 (C.A.) (QL)

R. v. R.B. (2002), 214 Nfld. \& P.E.I.R. 216 (Nfld. S.C. (T.D.))

R. v. R.C. (2002), 58 O.R. (3d) 257 (C.A.)

R. v. S.P., [2001] O.J. No. 2898 (Sup. Ct. J.) (QL)

$R$. v. Shearing, [2002] 3 S.C.R. 33, 2002 SCC 58

R. v. Stewart (2000), 148 C.C.C. (3d) 68,2000 BCCA 498

R. v. Sutherland (2001), 156 C.C.C. (3d) 264,2002 NSSC 49

R. v. Tatchell (2001), 207 Nfld. \& P.E.I.R. 131 (Nfld. S.C. (T.D.))

R. v. Thompson (200I), 52 O.R. (3d) 779 (C.A.)

R. v. W.C., [1999] M.J. No. 542 (Q.B.) (QL)

R. v. W.G. (2000), 46 W.C.B. (2d) 20 (Nfld. S.C. (T.D.))

R. v. W.P.N., [2000] N.W.T.J. No. 15, 2000 NWTSC 22 (QL)

Production and Disclosure Decisions - Decisions on Likely Relevance (27)

DeCisions in Which RECORdS WeRE Found LIKELY RELEVANT (9):

**R. v. L.P.M. [2000] O.J. No. 4076 (Sup. Ct. J.) (QL)

**R. v. W.G. (2000), 46 W.C.B. (2d) 20 (Nfld. S.C. (T.D.))

R. v. C.S. (2000), 195 Nfld. \& P.E.I.R 104 (Nfld. S.C. (T.D.)) 
R. v. D.H. (2000), 258 A.R. 346, 2000 ABPC 20 (Youth Div.)

R. v. G.P.J., [2001] 6 W.W.R. 734, $2001 \mathrm{MBCA} 18$

R. v. K.A.G. (2001), 192 N.S.R. (2d) 5, 2001 NSFC 1

R. v. L.G., [2000] O.J. No. 5090 (Sup. Ct. J.) (QL)

R. v. R.B. (2002), 214 Nfld. \& P.E.I.R. 216 (Nfld. S.C. (T.D.))

**R. v. W.C., [1999] M.J. No. 542 (Q.B.) (QL)

\section{DECisions IN Which SOME RECORDS FOUND Likely RELEVANT (4):}

*R. v. W.P.N., [2000] N.W.T.J. No. 15, 2000 NWTSC 22

R. v. D.P.F. (2001), 199 Nfld. \& P.E.I.R. 219 (Nfld. S.C.(T.D.))

R. v. Hudson, [2001] O.J. No. 5456 (Sup. Ct. J.) (QL)

R. v. L.S., [2000] O.J. No. 3991 (Sup. Ct. J.) (QL)

\section{DeCisions in Which ReCoRdS WeRE FoUnd NOT LiKely RELEYANT (14):}

R. v. Batte (2000), 49 O.R. (3d) 321 (C.A.)

R. v. D.M. (2000), 49 W.C.B. (2d) 217 (Ont. Sup. Ct.)

R. v. D.W.L. (2001), 156 C.C.C. (3d) 152,2001 NSCA 111

R. v. E.A.N. (2000), 45 W.C.B. (2d) 267, 2000 BCCA 61

R. v. M.A.S. (2000), 48 W.C.B. (2d) $171,2000 \mathrm{MBQB} 189$

R. v. M.G. (2001), 49 W.C.B. (2d) 171 (Man. Prov. Ct.)

R. v. N.P., [2001] O.J. No. 1828 (Sup. Ct. J.) (QL)

R. v. P.E. (2000), 45 W.C.B. (2d) 371 (Ont. C.A.)

R. v. P.J.S., [2000] Y.J. No. 119, 2000 YTSC 23 (QL)

R. v. R.C. (2002), 58 O.R. (3d) 257 (C.A.)

R. v. S.P., [2001] O.J. No. 2898 (Sup. Ct. J.) (QL)

R. v. Sutherland (2001), 156 C.C.C. (3d) 264, 2002 NSSC 49

R. v. Tatchell (2001), 207 Nfld. \& P.E.I.R. 131 (Nfld. S.C. (T.D.))

R. v. Thompson (2001), 52 O.R. (3d) 779 (C.A.)

*indicates disclosure decision, not disclosed

**indicates disclosure decision, records or portion of records disclosed 


\section{APPENDIX B: POST-DARRACH DECISIONS ANALYZED (22)}

R. v. Badgerow, [2000] O.J. No. 5446 (QL) (admissible).

R. v. D.A.K., [2001] Q.J. No. 6170 (C.Q. (Crim. \& Pen. Div.)) (ruled admissible).

R. v. D.J.W. (2003), 58 W.C.B. (2d) 314 (Ont. Sup. Ct. J.) (withdrawn).

R. v. D.S. (2003), 58 W.C.B. (2d) 289 (Ont. Sup. Ct. J.) (partially admissible).

R. v. Dempsey (2001), 51 W.C.B. (2d) 519, 2001 BCSC 371 (inadmissible).

R. c. Dikıakis, [2002] J.Q. no. 2876 (QL)* (inadmissible).

R. v. B.W.E. (2002), 55 W.C.B. (2d) 240,2002 SKPC 82 (admissible).

R. v. K.K. (2002), 224 Nfld. \&P.E.I.R. 302 (Nfld. S.C. (T.D.)) (inadmissible).

R. v. Kynoch, [2002] A.J. No. 1256, 2002 ABQB 912 (QL) (admissible).

R. v. Lalo (2003), 58 W.C.B. (2d) 288, 2003 NSSC 157 (partially admissible).

Lavoie c. R. (2003), J.E. 2003-565 (Qc. C.A.) (new trial ordered basis of procedural errors in consideration of $\mathrm{s} .276$ application).*

R. v. McDonald (2003), 58 W.C.B. (2d) 435, 2003 SKQB 165 (inadmissible).

R. v. N. P., [2001] O.J. No. 1825 (Sup. Ct. J.) (QL) (inadmissible).

R. v. Nelson (2001), 156 C.C.C. (3d) 248, 2001 BCCA 351 (inadmissible).

R. v. Porter (2001), 50 W.C.B. (2d) 160 (Ont. Sup. Ct. J.) (inadmissible).

R. v. R.A. (2002), 209 Nfld. \& P.E.I.R. 264, 2002 NFCA 7 (admissible).*

R. v. R.H.B. (2002), 162 B.C.A.C. 107,2002 BCCA 1 (admissible).*

R. v. S.A., [2002] O.J. No. 1218 (Ct. J.) (QL) (inadmissible).

R. v. T.S. (2003), 59 W.C.B. (2d) 484 (Ont. Ct. J.) (admissible).

R. v. Temertzoglou (2002), 56 W.C.B. (2d) 184 (Ont. Sup. Cl. J.) (admissible).

R. v. Toms (2001), 205 Nfld. \& P.E.I.R. 352 (Nfld. S.C. (T.D.)) (admissible).

R. v. W.S., [2003] O.J. No. 1289 (Ct. J.) (QL) (ruled on application of s. 276 - no ruling on admissibility).

\section{Disposition:}

- 10/22 admissible or partially admissible

- $9 / 22$ inadmissible

- $3 / 22$ no ruling on admissibility 